\title{
Trophic level-based indicators to track fishing impacts across marine ecosystems
}

\author{
Lynne Shannon ${ }^{1, *}$, Marta Coll ${ }^{2,12}$, Alida Bundy ${ }^{3}$, Didier Gascuel ${ }^{4}$, \\ Johanna J. Heymans ${ }^{5}$, Kristin Kleisner ${ }^{6,7}{ }^{\text {, Christopher P. Lynam }}{ }^{8}$, Chiara Piroddi ${ }^{9}$, \\ Jorge Tam ${ }^{10}$, Morgane Travers-Trolet ${ }^{11}$, Yunne Shin ${ }^{12,1}$ \\ ${ }^{1}$ Marine Research Institute and Department of Biological Sciences, University of Cape Town, Private Bag X3, \\ Rondebosch 7701, South Africa \\ ${ }^{2}$ Institut de Ciències del Mar (ICM-CSIC), Passeig Marítim de la Barceloneta, 37-49, 08003 Barcelona, Spain \\ ${ }^{3}$ Bedford Institute of Oceanography, Ocean Ecosystem Science, PO Box 1006, Dartmouth, Nova Scotia B2Y 4A2, Canada \\ ${ }^{4}$ Université Européenne de Bretagne, Agrocampus Ouest, UMR985 Écologie et santé des écosystèmes, \\ 65 route de Saint Brieuc, CS 8421, 35042 Rennes cedex, France \\ ${ }^{5}$ Scottish Association for Marine Science, Scottish Marine Institute, Oban, Argyll PA371QA, UK \\ ${ }^{6}$ Sea Around Us Project, University of British Columbia, 2202 Main Mall, Vancouver, BC V6T 1Z4, Canada \\ ${ }^{7}$ National Oceanographic and Atmospheric Administration (NOAA), Northeast Fisheries Science Center, 166 Water Street, \\ Woods Hole, Massachusetts 02543-1026, USA \\ ${ }^{8}$ Centre for Environment, Fisheries \& Aquaculture Science (Cefas), Lowestoft Laboratory, Pakefield Road, Lowestoft, \\ Suffolk NR33 0HT, UK \\ ${ }^{9}$ Joint Research Centre, European Commission, Via E. Fermi 2749, Ispra (VA) 21027, Italy \\ ${ }^{10}$ Instituto del Mar del Perú (IMARPE), Esquina Gamarra y Gral. Valle s/n, Apartado 22, Callao, Lima, Peru \\ ${ }^{11}$ IFREMER, Fisheries Laboratory, 150 quai Gambetta, BP699, 62321 Boulogne/mer, France \\ ${ }^{12}$ Institut de Recherche pour le Développement (IRD), UMR EME 212, CRH, avenue Jean Monnet, CS 30171,
} 34203 Sète cedex, France

\begin{abstract}
Trophic level (TL)-based indicators have been widely used to examine fishing impacts in aquatic ecosystems and the induced biodiversity changes. However, much debate has ensued regarding discrepancies and challenges arising from the use of landings data from commercial fisheries to calculate TL indicators. Subsequent studies have started to examine survey-based and model-based indicators. In this paper, we undertake an extensive evaluation of a variety of TL indicators across 9 well-studied marine ecosystems by making use of model- as well as surveyand catch-based TL indicators. Using detailed regional information and data on fishing history, fishing intensity, and environmental conditions, we evaluate how well TL indicators are capturing fishing effects at the community level of marine ecosystems. Our results highlight that the differences observed between TL indicator values and trends is dependent on the data source and the TL cut-off point used in the calculations and is not attributable to an intrinsic problem with TLbased indicators. All 3 data sources provide useful information about the structural changes in the ecosystem as a result of fishing, but our results indicate that only model-based indicators represent fishing impacts at the whole ecosystem level.
\end{abstract}

KEY WORDS: Trophic level · Global comparison · Indicator · Survey · Catch · Ecosystem model · Trophic spectra C Convention on Biological Diversity $\cdot$ Food webs $\cdot$ Ecosystem approach to fisheries

\section{INTRODUCTION}

The trophic level (TL) identifies the position of organisms (or groups of organisms) within food webs by identifying the source of energy for each organism. TL was first defined as an integer value (Lindeman 1942), providing an average number of steps in food webs, placing species or functional groups into a 


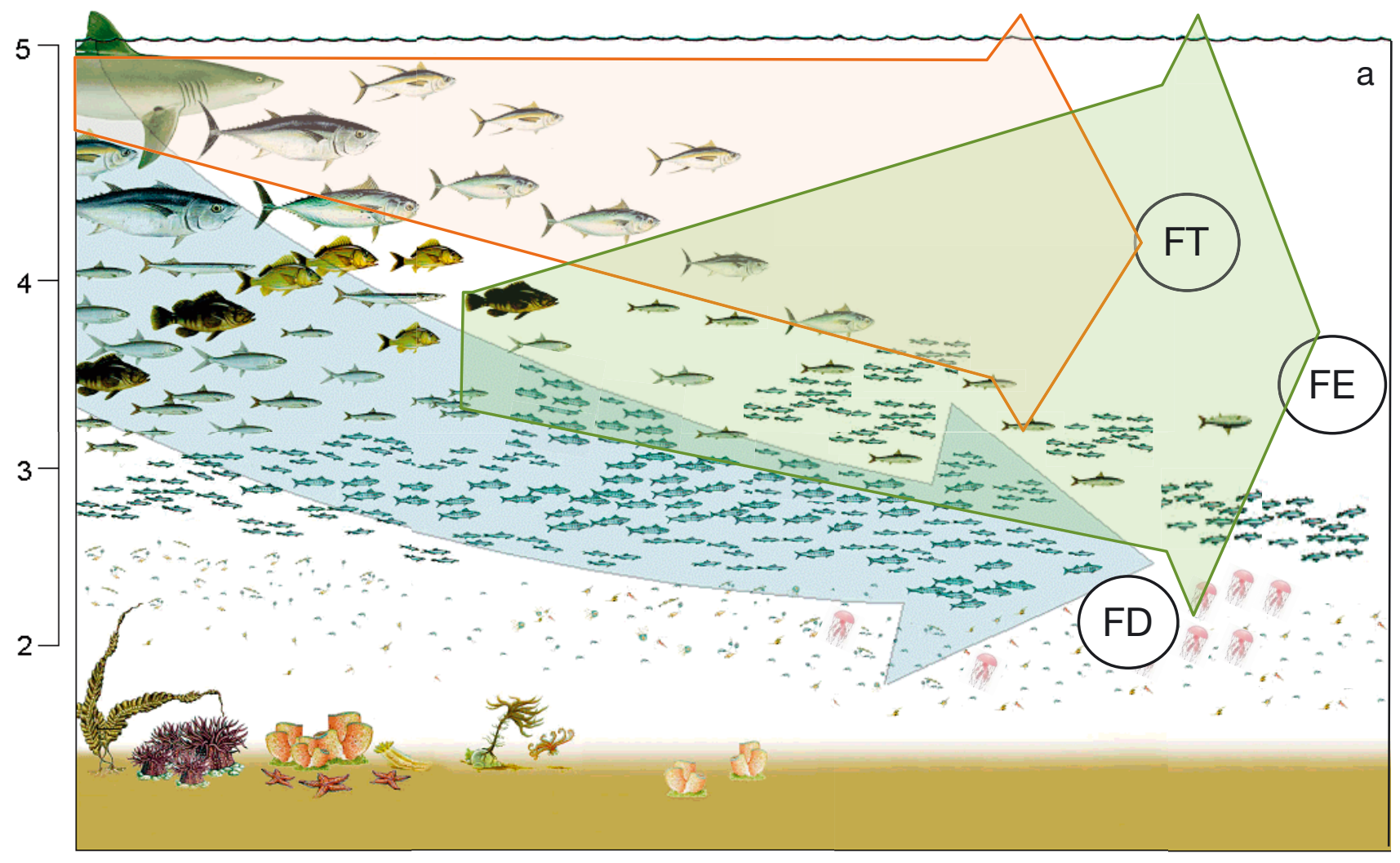

Fig. 1. Schematic representations of historical overfishing and fisheries expansion used to discuss results. (a) Exploitation through the food web (trophic level given on $y$-axis). Graph modified from original graph design by Daniel Pauly; Artist: Rachel Atanacio. (b) Exploitation histories (main fishing scenarios) in time and space. FD: 'fishing down' the food web (Pauly et al. 1998); FT: 'fishing through' the food web (Essington et al. 2006); FE: 'fisheries expansion' (Morato et al. 2006, Swartz et al. 2010) towards further and deeper areas, or to alternative species, leading to ecosystem overfishing

simple scheme, and quantifying the efficiencies with which energy is transferred from one level to the next. The concept was later modified to be fractional (Odum \& Heald 1975), which better accounts for omnivory, a feature prevalent in marine food webs. Following an established convention, fractional trophic levels are calculated by assigning producers (and often also detritus) to TL 1 (e.g. phytoplankton), and consumers to a TL of 1 plus the average TL of their prey, weighted by their proportion in weight in the predator's diet (Pauly et al. 2000).

As fishing selectively removes organisms from the food web, the trophic and size structure of the ecosystem may be altered (e.g. Pauly et al. 1998, Shin et al. 2005). Consequently, size-based indicators have been widely and successfully used to measure fishing impacts and ecosystem changes (Jennings et al. 1999, Bianchi et al. 2000, Shin et al. 2005, Blanchard

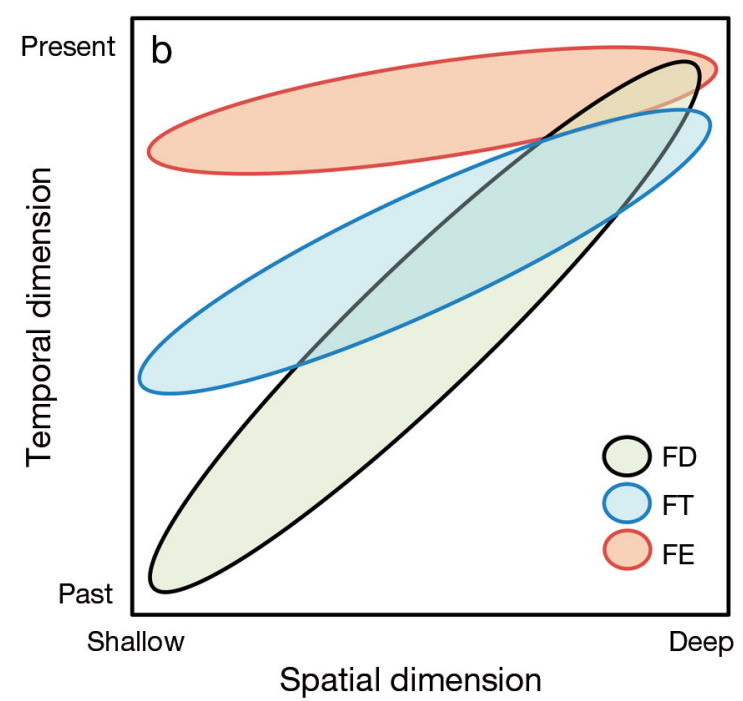

et al. 2010). TL-based indicators may also be used to capture this effect. A simple change in trophic structure due to the fisheries-induced decrease in abundance of higher TL species, followed by fishing at lower trophic levels, is termed 'fishing down' the food web (Pauly et al. 1998) (Fig. 1). This pattern is documented in numerous ecosystems around the globe as a decrease in the mean TL (MTL) of the landings (e.g. east and west coasts of Canada, Pauly et al. 2001; Chile, Arancibia \& Neira 2005; China, Pang \& Pauly 2001; North Sea, Heath 2005; Thailand, 
Christensen 1998; Caribbean, Wing \& Wing 2001; West Africa, Laurans et al. 2004, Gascuel et al. 2007; Gulf of Maine, USA, Steneck et al. 2004; India, Bhathal \& Pauly 2008; Adriatic Sea, Coll et al. 2010a; and see www.fishingdown.org). The concept of 'fishing down' the food web has attracted much interest and debate (e.g. Caddy et al. 1998) and has subsequently been refined to exclude abundant species at low TLs in the calculation of TL of the landings (Pauly \& Palomares 2000, Pauly \& Watson 2005, Stergiou \& Christensen 2011) so as to better reflect changes in the upper TLs of individual ecosystems. In particular, the Marine Trophic Index (MTI) is defined by using a minimum threshold TL value, conventionally of 3.25 (Pauly \& Watson 2005). The Conference of the Parties to the Convention on Biological Diversity (CBD) identified TL-based indicators as key indicators for measuring biodiversity changes, and listed the MTI (CBD 2004) as one of its headline indicators (Butchart et al. 2010).

Since then, the concept of MTL of landings has been further explored and additional hypotheses suggested to explain observed patterns. In a global comparison, Essington et al. (2006) show that 'fishing down' the food web, as defined above, can be detected in the North Atlantic, whereas they show that a more typical scenario termed 'fishing through' the food web seems to have occurred elsewhere, characterised by sequential addition of lower TLs that are fished, as opposed to sequential removal of TLs by fishing (i.e. 'fishing down'). That is, they highlight the fact that in some systems, catches of apex predators have increased or have been maintained, while fisheries have expanded to also catch species at lower TLs (Fig. 1). In contrast, Morato et al. (2006) suggest that the expansion of fisheries ('fisheries expansion') into deeper waters (fishing deeper in the food web) and further offshore is masking the 'fishing down' effect through the inclusion of new fishing grounds and new, higher TL species caught (Swartz et al. 2010). 'Fishing up' the food web is defined as the addition of new, high-TL species to catches over time (see Stergiou \& Tsikliras 2011). The latter authors maintain that 'fishing through' and 'fishing up' the food web are related to technical issues (data availability and fishing behaviour or extent of fishing).

These different processes and the recent debate around the usefulness of TL-based indicators highlight the fact that, when based on commercial landings data, TL-based indicators can be difficult to interpret as their behaviour is strongly linked to the multispecies fishing strategy in time, in space and across trophic levels, such that ecosystem-based indicators that rely on survey data diverge from the catch-based MTL (Branch et al. 2010). These concepts and discussions (in particular 'fishing down' the food web) have been at the core of increasing concern regarding the impact of fishing on marine ecosystems.

There are additional concerns about TL-based indicators that add fuel to the debate, such as the difficulties associated with obtaining accurate catch data (i.e. a complete accounting of removals from a system) as opposed to nominal landings, and the fact that non-commercial or unexploited species are not reflected in landings data (e.g. Zeller \& Pauly 2007). Beyond the issues concerning catch-based TL indicators, there is also the uncertainty involved in the estimation of a single TL for species with variable ontogeny. The TL of species varies with size and can vary in time and space (Jennings et al. 2002, Vinagre et al. 2012), necessitating some caution in TL-based indicator assessments (Caddy et al. 1998). However, the effect of ontogenetic changes in the TL of species was found to be negligible within-species in comparison with between-species effects (i.e. changes in the relative abundance of species) (Pauly et al. 2000). Nevertheless, although ontogenetic effects are likely to be small in catch-based indicators that only account for recruited stages, they may be important to consider in community indicators such as those based on survey data. Model-based TL indicators that capture ontogenetic change are better equipped to handle ontogenetic changes in $\mathrm{TL}$, since these changes are defined within the model.

Below, we describe a suite of TL-based indicators, often used to quantify fishing effects on the trophic structure of food webs, and summarise the processes leading to change in the indicators. We then interpret trends in indicators using catch, survey and modelled data for multiple ecosystems in relation to fishing pressure and fisheries management. From this structured comparative analysis, we draw guidelines for the use and interpretation of TL indicators in ecosystem level assessments as required by the Convention on Biological Diversity (CBD 2004) and the European Marine Strategy Framework Directive (2008/56/EC).

\section{Data used to calculate trophic level-based indicators}

Three sources of data are available from which TLbased indicators can be calculated, each having advantages and constraints (Table 1). Landings data are the most readily available fisheries-related data, 
Table 1. Advantages and constraints pertaining to trophic level (TL)-based indicators calculated from 3 sources of data: landings, surveys and models

\begin{tabular}{|c|c|c|}
\hline Data source & Advantages & Constraints \\
\hline \multirow[t]{4}{*}{ Landings } & Readily available & Restricted to the exploited community \\
\hline & Include all gears & Not always representative of all catches taken (IUU) \\
\hline & Long time series & $\begin{array}{l}\text { Fishers' behaviour, management strategies and market } \\
\text { forces affect changes in landings }\end{array}$ \\
\hline & $\begin{array}{l}\text { Includes species that may not be effectively } \\
\text { sampled by trawl surveys (e.g. small pelagics, } \\
\text { invertebrates) }\end{array}$ & $\begin{array}{l}\text { Pre-recruit stages and non-commercial species poorly } \\
\text { sampled }\end{array}$ \\
\hline \multirow[t]{3}{*}{ Surveys } & $\begin{array}{l}\text { Reflect actual changes in communities } \\
\text { (not influenced by market forces etc.) }\end{array}$ & $\begin{array}{l}\text { Species sampled dependent on survey design and } \\
\text { coverage }\end{array}$ \\
\hline & Include non-targeted species & Time series often short \\
\hline & Often also include young stages and pre-recruits & Often restricted to the demersal community \\
\hline \multirow[t]{4}{*}{ Models } & Aim to cover the full community & $\begin{array}{l}\text { Dependent on data available to parameterize poorly } \\
\text { known groups }\end{array}$ \\
\hline & Can account for changes in species' TL over time & Dependent on understanding of predation process \\
\hline & $\begin{array}{l}\text { Provide simulation platforms for exploring } \\
\text { multiple drivers of TL changes in communities }\end{array}$ & $\begin{array}{l}\text { Dependent on reliable diet data or surrogates being } \\
\text { available }\end{array}$ \\
\hline & & $\begin{array}{l}\text { Uncertainty linked to model structure, parameterization, } \\
\text { and assumptions }\end{array}$ \\
\hline
\end{tabular}

since some attempt is usually made to monitor catches in any given marine exploited area (Garibaldi 2012). Therefore, they are the basis for most fisheries assessments, including single stock assessments and models (Hilborn \& Walters 1992). Since the assumption made when using catch-based indicators as indicators of ecosystem state is that landings are representative of the biomass of species present in the ecosystem, catch-based TL indicators are intended to represent changes in trophic structure of the exploited system due to fishing. However, and despite important efforts to collect and harmonize catch data by country (Garibaldi 2012), landings do not necessarily represent the actual catches taken - which encompass illegal, unregulated and unreported (IUU) catches, as well as discards and catches from the recreational and subsistence sectors (Zeller \& Pauly 2007). In addition, and maybe more importantly, a change in landings is rarely representative solely of a change in the state of the fish community since landings are also dependent on fishers' behavioural responses to fisheries management and market forces. As such, catch-based indicators are best considered as indicators of pressure rather than state (Degnbol \& Jarre 2004).

Fisheries independent (scientific) survey-based indicators may better reflect changes in the actual community, because unlike catch-based TL indicators they are not subject to confounding factors such as market forces, fleet dynamics or under-reporting. Furthermore, consideration of the survey community enables tracking of non-target species caught as bycatch, and species indirectly affected by altered food web interactions (including cascading effects and predator release processes). However, survey-based TL is subjected to the constraints of the sampling design of the survey, selectivity of the survey gear, species catchability and availability, and selective recording of species (Jouffre et al. 2010). One type of survey (or one gear type) is unlikely to be representative of the whole community, and ways of combining different kinds of surveys should be sought. For example, demersal trawl surveys mainly capture benthic and demersal species, but can also include some pelagic species if they are available and vulnerable to the survey gear. Conversely, pelagic surveys typically have low catchability of non-pelagic species and do not capture transitions between demersaland pelagic-dominated communities in response to exploitation (e.g. Shannon et al. 2009). In contrast, indicators from landings consider all gears used in a given ecosystem and have the potential to take into account all species caught, including crustaceans, small pelagics and cephalopods, if properly reported. Moreover, and even if surveys and landings encompassed the same range of species, 2 important differences in the data would remain. First, in many ecosystems, surveys started only recently and thus 
provide only short time series. Landings data cover a longer period, often starting in the 1950s according to FAO statistics, or sometimes earlier in national databases. The second difference is due to the demographic characteristics of the assemblages sampled. Surveys often target small, young fish in order to inform recruitment indices for stock assessments, whereas pre-recruit stages are poorly sampled commercially. In contrast, more valuable larger (older) fish usually dominate the commercial landings, and the size range is often limited by an enforced 'minimum landing size'.

Ecosystem models can also be used to calculate the TL of the modelled community, and provide a simulation platform for further examination of the potential usefulness of the TL of the community as an indicator of fishing effects under multiple drivers, such as environmental changes and ecosystem effects (e.g. Coll et al. 2008, 2009, Araújo \& Bundy 2012). The advantage of TL-based indicators from models is that they capture the dynamics of the whole community rather than just the landed or surveyed community, spanning both pelagic and demersal organisms, from low TL species to top predators. Further, model-based TL indicators are also able to take into account changes in the TL of each species over time as their food changes due to changes in modelled prey species, whereas in the other indices the TL usually stays constant over time. However, TLs based on modelled communities are dependent on a well understood predation process, grounded in reliable diet data. Further, these models should be fitted to data and validated with external observations and knowledge (e.g. Shannon et al. 2004, Coll et al. 2008, TraversTrolet et al. 2014), thus minimising the uncertainty associated with these tools.

TL-based indicators $\left(\mathrm{TL}_{\mathrm{IND}}\right.$ ) are calculated as the mean trophic position of all species, weighted by the relative biomass of each species in the landings, in the surveys or in the modelled community:

$$
\mathrm{TL}_{\mathrm{IND}}=\sum_{i=1}^{\mathrm{n}} X_{i} \cdot \mathrm{TL}_{i} / X_{\mathrm{L}}
$$

where $\mathrm{TL}_{i}$ is the trophic level of species $i, X_{\mathrm{L}}$ is total landings (for TL of the landings) or total biomass (for TL of surveyed or modelled ecosystems) and $X_{i}$ is the landings or biomass of species $i$. See Table 2 for further details.

These TL-based indicators can be complemented by trophic spectra, which represent the distribution of biomass (based on model or survey) or landings by TL (Gascuel et al. 2005), similar to a trophic pyramid but using fractional TLs. Trophic spectra have been proposed as indicators of the trophic structure and functioning of aquatic ecosystems in a fisheries context, and will be used here to analyse changes that have occurred in both the ecosystem fishing strategy and the underlying ecosystem. Trophic spectra have been used to test the impact of management measures on ecosystems (e.g. Colléter et al. 2012, Valls et al. 2012), and to quantify the effects of exploitation on trophic structure both in theoretical studies (Gascuel \& Pauly 2009) and for specific case studies (Guinea, Gascuel et al. 2011; Benguela, Gasche et al. 2012; Bay of Biscay, Lassalle et al. 2012).

\section{Processes underlying TL-based indicator trajectories}

Ecosystem changes due to fishing are frequently complex, reflecting change in processes at multiple levels. High-TL species are usually more sensitive to fishing due to their lower rates of turnover (Pauly et al. 1998, Gascuel et al. 2008). Even if not specifically targeted, they are often the first and most affected by fisheries. Their decrease in abundance has produced 'trophic cascades', or increased abundance of smaller organisms (e.g. intermediate predators, forage fish and invertebrates) due to predation release both in coastal areas and the open ocean (Bundy \& Fanning 2005, Frank et al. 2005, Scheffer et al. 2005, Ward \& Myers 2005, Baum \& Worm 2009). These low TL organisms may become abundant in highly exploited ecosystems, and later may themselves become important fishing resources (e.g. Anderson et al. 2011a,b). This typical chain reaction to fishing is generally well captured by TL-based indicators, which would decrease under fishing pressure. But the magnitude of the fishing impact, illustrated by the subsequent and sequential depletion of small pelagic fish and invertebrates documented in many ecosystems (e.g. Anderson et al. 2011a,b, Pikitch et al. 2012), can complicate the signals that indicators are meant to capture. These processes of 'fishing further down' the marine food web following depletions and proliferations are likely to have unprecedented implications for the structure and functioning of marine food webs, and thus for the signals that ecosystem indicators represent.

In fact, some puzzling trends have already been detected using TL-based indicators: in upwelling ecosystems and other subtropical systems, TL-based indicators calculated from landings tend to increase when small pelagic fish have been targeted and subsequently depleted (Cury et al. 2005). The increase in 
Table 2. Trophic level (TL)-based indicators examined in this paper

\begin{tabular}{|c|c|c|}
\hline TL Indicator & Symbol & Calculation \\
\hline \multicolumn{3}{|l|}{ Landings-based } \\
\hline \multirow[t]{2}{*}{ Trophic level of the landed catch } & $\mathrm{TL}_{\mathrm{L}}$ & $\mathrm{TL}_{\mathrm{L}}=\sum_{i=1} Y_{i} \cdot \mathrm{TL}_{i} / Y_{\mathrm{L}}$ \\
\hline & & $\begin{array}{l}\text { where } Y_{\mathrm{L}} \text { is total landings, } Y_{i} \text { is the landing of species } i_{\text {, }} \\
\text { and } \mathrm{TL}_{i} \text { is the trophic level of species } i\end{array}$ \\
\hline Marine trophic index with cut-off at TL 3.25 & $\mathrm{MTI}_{3.25}$ & $\mathrm{MTI}_{3.25}=\sum_{i=1}^{\mathrm{n}} Y_{\mathrm{TL} i \geq 3.25} \cdot \mathrm{TL}_{i} / Y_{\mathrm{L}(\mathrm{TL} i \geq 3.25)}$ \\
\hline Marine trophic index with cut-off at TL 4.0 & $\mathrm{MTI}_{4.0}$ & $\mathrm{MTI}_{4.0}=\sum_{i=1}^{\mathrm{n}} Y_{\mathrm{TL} i \geq 4.0} \cdot \mathrm{TL}_{i} / Y_{\mathrm{L}(\mathrm{TL} i \geq 4.0)}$ \\
\hline Landings at TL 3.5 and 4.5 & Landings $_{3.5 \& 4.5}$ & $\begin{array}{l}\text { Trends in landings at } \mathrm{TL}=3.5 \text { and } \mathrm{TL}=4.5 \text { plotted separa- } \\
\text { tely to inform interpretation of other indicators (trophic spectra) }\end{array}$ \\
\hline \multicolumn{3}{|l|}{ Survey-based } \\
\hline \multirow[t]{2}{*}{ Trophic level of the surveyed community } & $\mathrm{TL}_{\mathrm{SC}}$ & $\mathrm{TL}_{\mathrm{SC}}=\sum_{i=1}^{i} B_{i} \cdot \mathrm{TL}_{i} / B_{\mathrm{T}}$ \\
\hline & & $\begin{array}{l}\text { where } B_{\mathrm{T}} \text { is total biomass of the survey, } B_{i} \text { is the biomass } \\
\text { (or biomass index) of each species } i \text { in the survey, } \\
\text { and } \mathrm{TL}_{i} \text { is the trophic level of species } i\end{array}$ \\
\hline $\begin{array}{l}\text { Trophic level of the surveyed community } \\
\text { with cut-off TL of } 3.25\end{array}$ & $\mathrm{TL}_{\mathrm{SC} 3.25}$ & $\mathrm{TL}_{\mathrm{SC} 3.25}=\sum_{i=1}^{\mathrm{n}} B_{\mathrm{TL} i \geq 3.25} \cdot \mathrm{TL}_{i} / B_{\mathrm{T}(\mathrm{TL} i \geq 3.25)}$ \\
\hline $\begin{array}{l}\text { Trophic level of the surveyed community } \\
\text { with cut-off TL of } 4.0\end{array}$ & $\mathrm{TL}_{\mathrm{SC} 4.0}$ & $\mathrm{TL}_{\mathrm{SC} 4.0}=\sum_{i=1}^{\mathrm{n}} B_{\mathrm{TL} i \geq 4.0} \cdot \mathrm{TL}_{i} / B_{\mathrm{T}(\mathrm{TL} i \geq 4.0)}$ \\
\hline \multicolumn{3}{|c|}{ Model-based (from Ecopath with Ecosim [EwE] models fitted to catch and abundance time series) } \\
\hline \multirow{2}{*}{$\begin{array}{l}\text { TL of the modelled community (whole eco- } \\
\text { system excluding zooplankton organisms } \\
\text { and primary producers) }\end{array}$} & $\mathrm{TL}_{\mathrm{MC}}$ & $\mathrm{TL}_{\mathrm{MC}}=\sum_{i=1}^{\mathrm{n}} B_{\mathrm{M} i} \cdot \mathrm{TL}_{i} / B_{\mathrm{MT}}$ \\
\hline & & $\begin{array}{l}\text { where } B_{\mathrm{MT}} \text { is total biomass of the modeled ecosystem, } \\
B_{\mathrm{Mi}} \text { is the biomass of each species } i \text { in the model, and } \mathrm{TL}_{i} \\
\text { is the trophic level of species } i \text { as an output of the model }\end{array}$ \\
\hline $\begin{array}{l}\text { Trophic level of the modelled community } \\
\text { with cut-off TL of } 3.25\end{array}$ & $\mathrm{TL}_{\mathrm{MC} 3.25}$ & $\mathrm{TL}_{\mathrm{MC} 3.25}=\sum_{i=1}^{\mathrm{n}} B_{\mathrm{M} i \geq 3.25} \cdot \mathrm{TL}_{i} / B_{\mathrm{MT}(\mathrm{TL} i \geq 3.25)}$ \\
\hline $\begin{array}{l}\text { Trophic level of the modelled community } \\
\text { with cut-off TL of } 4.0\end{array}$ & $\mathrm{TL}_{\mathrm{MC} 4.0}$ & $\mathrm{TL}_{\mathrm{MC} 4.0}=\sum_{i=1}^{\mathrm{n}} B_{\mathrm{Mi} i 4.0} \cdot \mathrm{TL}_{i} / B_{\mathrm{MT}(\mathrm{TL} i \geq 4.0)}$ \\
\hline
\end{tabular}

the TL of the landings in this case is a sign of overexploitation of the once abundant lower TL species, rather than recovery of high-TL organisms (Shannon et al. 2010). This is also the case when invertebrates are targeted and heavily exploited, as highlighted in global trends reported by Anderson et al. (2011a). In highly exploited ecosystems, such as the North Western Mediterranean Sea, small pelagic fish currently represent the bulk of commercial catches and have been heavily fished or overfished for many years (Palomera et al. 2007, FAO-GFCM 2013, STECF 2013). Since large organisms in the Mediterranean Sea were depleted decades ago (e.g. notably post World War II in the Adriatic Sea; Lotze et al. 2011), the increase in the TL of the Mediterranean catch reflects the ultimate depletion of small organisms in the ecosystem (Coll et al. 2008, 2010a,b).

Therefore, it is essential to understand the fishing history in a given ecosystem and processes underlying observed trajectories in TL-based indicators. While 'fishing down' and 'fishing through' processes may lead to a decline in TL-based indicators (both can be considered as patterns characterising 'historical overfishing'), the 'expansion of fisheries' (Fig. 1) may lead to alternative trajectories, including what may be described as 'fishing further down' and 'ecosystem overfishing', where all trophic levels of an ecosystem are subjected to overexploitation due to 
different fishing strategies overlapping, and where ecosystem impacts (such as trophic cascades and depletions) intersect. During a recovery phase, TLbased indicators could initially decline, for example if fishing pressure by all fleets were reduced concurrently, allowing short-lived, low-TL pelagic species to recover rapidly. Long-lived, high-TL piscivores and benthivores would need a longer time to recover, leading to a decline in overall TL prior to an increase in the longer term.

Global fishing intensity has been increasing since 1950 (Watson et al. 2013). In this study, we argue that historical evolution of the ecosystem state (trophic structure) and of the fishing strategy (species targeted, gear used, fishing effort), and the environment (productivity level) are 3 important factors determining how fishing impacts the trophic structure of the ecosystem, and thus how TL-based indicators should be interpreted. Therefore, our hypothesis is that (1) the message conveyed by TL-based indicators may change with time as fisheries develop, management measures are implemented, and/or small pelagic and invertebrate biomass changes due to environmental drivers and/or trophic cascades, and (2) TL-based indicators may provide information on different phases of ecosystem degradation. In particular, the 'phase' of exploitation and productivity (either characterised by known historical overfishing patterns directed towards specific fractions of the ecosystem, or recent expansion of fisheries across the ecosystem, with respect to productivity; Fig. 1), is likely to play an important role in the observed trajectories of TL-based indicators that describe the overall effects of fishing on the ecosystems in question.

\section{Aims of the paper}

In this study, using 9 well-documented ecosystems as case studies, the concerns about TL-based indicators discussed above are explored with respect to their use in interpreting the ecosystem effects of fishing.

The key question examined in this paper is how well do TL-based indicators capture fishing impacts at the community level of marine ecosystems? The aim is to systematically evaluate patterns in TLs, accounting for the mechanisms behind the changes in TL-based indicators. In doing so, we explore how to use these indicators correctly (e.g. at appropriate geographic scales and with an understanding of the developmental level of the fishery and productivity regimes) to avoid misinterpretations and misunder- standings. To this end, landings-based, survey-based and model-based TL indicators are compared across 9 ecosystems using different thresholds for minimum TLs to be included in the indicators, and are complemented with trophic spectra analyses. Ecosystems were selected in order to cover various configurations of latitude, size, depth and fishing intensity. For each of the ecosystems, an Ecosim model fitted to time series data was available from previous studies. We also examine global correlations (combining data from all ecosystem case studies), and correlations within each individual ecosystem to explore whether generalities can be determined.

\section{METHODS}

\section{TL indicator series: catch, surveys and models}

As previously mentioned, minimum thresholds for TLs are often used to exclude lower TL species from TL indicators, which tend to be present at higher biomass than high-TL species, and are more sensitive to environmental variability. The most popular threshold is that proposed by Pauly \& Watson (2005): TL $\geq 3.25$ (referred to as the $\mathrm{MTI}_{3.25}$; Table 2), which excludes forage fish and smaller organisms. Thus, $\mathrm{MTI}_{3.25}$ was proposed as a more suitable indicator to monitor the ocean's health (e.g. Pauly \& Watson 2005, Butchart et al. 2010) than mean trophic level of landings $\left(\mathrm{TL}_{\mathrm{L}}\right)$, which may also capture environmental dynamics rather than only fishing impacts on marine ecosystems.

Other minimum thresholds of the $\mathrm{TL}_{i}$ values have been used since the proposition of the $\mathrm{MTI}_{3.25}$ (Branch et al. 2010). In our study, we consider an additional threshold of 4.0 in $\mathrm{MTI}_{4.0}$, which is simply the $\mathrm{TL}_{\mathrm{L}}$ with the lower limit (cut-off) TL changed from 3.25 to 4.0, following Stergiou (2005) and Essington et al. (2006). The aim of a cut-off of TL at 4.0 is to examine changes within the apex predator community while excluding small and medium pelagic fish, some of which have TLs above 3.25 and which are still subject to large natural fluctuations in abundance. Some examples of these sorts of fishes are the Peruvian anchoveta Engraulis ringens (TL $=3.3$ to 3.6; Hückstädt et al. 2007, Marzloff et al. 2009), herring Clupea harengus on the Western Scotian Shelf, Canada (TL $=3.85$; Araújo \& Bundy 2012) and anchovy Engraulis capensis off South Africa (TL $=3.00$ to 3.50; Shannon et al. 2003, Watermeyer et al. 2008, Osman 2010, Van der Lingen \& Miller 2011). Further, under instances of expansion of fisheries, 'fishing 
down' trajectories may be masked by increases in the catches of higher TL species, which becomes evident when $\mathrm{MTI}_{4.0}$ is considered and/or when the Fishingin-Balance index, which indicates periods of expansion and contraction in the fishery (Pauly \& Palomares 2005), is monitored (Stergiou 2005).

Using fisheries-independent survey data, the MTL of the surveyed community $\left(\mathrm{TL}_{\mathrm{SC}}\right)$ is estimated (Table 2), which provides the trophic position of organisms sampled in research surveys (Rochet \& Trenkel 2003). This indicator can be calculated from survey biomass indices. Ideally, biomass estimates should be adjusted to reflect differential species catchability of the fishing gear, although this is notoriously difficult due to the dependence of catchability on fish size, behaviour and habitat type (Harley \& Myers 2001, Thorson et al. 2013). TL $L_{S C}$ which excludes fish with $\mathrm{TL}<3.25$ and 4.0 ( $^{\mathrm{TL}_{\mathrm{SC} 3.25}}$ and $\mathrm{TL}_{\mathrm{SC} 4.0}$, respectively), can also be calculated from the same survey data (Table 2). Similarly, model results can be modified to exclude components of the modelled community using different cut-offs as mentioned above, i.e. $\mathrm{TL} \geq 3.25$ and $4.0\left(\mathrm{TL}_{\mathrm{MC} 3.25}\right.$ and $\mathrm{TL}_{\mathrm{MC} 4.0 \text {, respectively, }}$ using notation $\mathrm{MC}$ for modelled community; Table 2).

\section{Analyses across ecosystems}

For 9 case studies (see Supplement 1, Fig. S1 and Table S1 at www.int-res.com/articles/suppl/m512p115 _supp.pdf) included in the IndiSeas project (Shin et al. 2012), trajectories of TL-based indicators were calculated from 1980 to 2010 (or shorter time series due to data availability) using landings data, survey data and modelled data. Nine TL-based indicators were calculated: (1) $\mathrm{TL}_{\mathrm{L}}$ (2) $\mathrm{MTI}_{3.25}$, (3) $\mathrm{MTI}_{4.0 \text {, (4) }}$

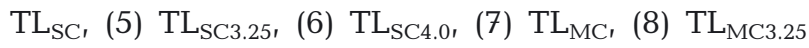
and (9) $\mathrm{TL}_{\mathrm{MC} 4.0}$ (Table 2). For ease of comparison between ecosystems, all indicators were normalized following Blanchard et al. (2010).

Data from catches and surveys were obtained by experts from the 9 ecosystems, and indicators were calculated using local datasets, as explained in Shin et al. (2010). To calculate TL-based indicators with different cut-offs, TLs by species or groups were obtained from local studies, modelling activities or, when unavailable (e.g. for specific species that were aggregated into a single model group), from FishBase (http://fishbase.org) and SeaLifeBase (http:// sealifebase.org). TLs adopted per species or species group per ecosystem are provided in Tables S2 \& S3 in Supplement 2 at www.int-res.com/articles/suppl/ m512p115_supp.pdf.
Ecosystem models used to calculate indicators were parameterized using the Ecopath with Ecosim (EwE) software and approach (Christensen \& Walters 2004). The 9 EwE models used in the study had been fitted to time series, previously validated, and were already well documented (see Supplement 1 and Table S1). The trophic models did not necessarily need to be fit to the most recent years, but selection was constrained to models for which the fitted timeseries overlapped well with the catch-based and survey-based TL indicator series.

All 9 of the above-mentioned TL-based indicators were compared using correlation analysis in each of the ecosystems analysed in an effort to establish whether important signals of change at the community level were consistently represented in all TLbased indicators or, on the contrary, were being masked by considering solely the $\mathrm{TL}_{\mathrm{L}}$ (i.e. by relying on commercial data and considering only exploited species). For each case study, an interpretation of the 9 TL-based indicators is provided.

In meta-analysis studies, data are generally pooled in order to provide a global picture. However, when large amounts of data are aggregated in this way, ecosystem signals may be masked. This was explored by comparing global patterns (combining data from all ecosystem case studies) with patterns within each individual ecosystem. Across all ecosystems, we examined how the TL-based indicators were correlated using all available data for these ecosystems spanning the period 1980 to 2010. This analysis was done assuming the same weight for all ecosystems after TL-based indicators per system had been calculated.

The relationship between the TL-based indicators and an indicator of fishing pressure (the ratio of landings to survey biomass) was also investigated using correlation analysis. This indicator of fishing pressure was selected because it is the simplest and most readily available indicator across the ecosystems examined (Shin et al. 2010). Relationships were also evaluated between TL-based indicators and modelled fishing effort and/or fishing mortality (when available, from the models fit to data), and with total landings.

In addition, we used correlation analysis to explore whether the set of 9 TL-based indicators may be influenced by environmental drivers such as sea surface temperature (SST) and productivity (i.e. chlorophyll $a_{i}$ chl a) for each of the 9 ecosystems. These environmental data were extracted for ecosystem study areas (H. Demarq pers. comm.); SST indicators were extracted from AVHRR/Pathfinder and MODIS, and chl $a$ from SeaWiFS and MODIS. 
All correlations were evaluated using Spearman's non-parametric rank order correlation coefficient (Spearman 1904), which is a measure of statistical dependence between 2 variables, ranging between -1 and 1 (perfect negative and positive correlation, respectively). The test assesses how well the relationship between 2 variables can be described using a non-linear monotonic function.

\section{Trophic spectra}

For the 9 ecosystems considered, trophic spectra representing the current distribution across TLs of surveyed biomass, landings and modelled biomass were built following a widely used methodology detailed in Gascuel et al. (2009a) and Gasche et al. (2012). Thus, the biomass of each species or functional group was distributed over a range of TLs according to a density probability log-normal function centred on the group MTL, where standard deviation measured within-group variability in TLs. The trophic spectrum is the single curve corresponding to the sum of surveyed biomass (or landings or modelled biomass) for all groups.

The evolution of these spectra over time was investigated by comparing average 5 yr periods when data were available: 1981-85, 1986-90, 1991-95, 1996-00, 2001-05 and 2006-10. In order to synthesize results, whole trophic spectra were not presented here. Instead, biomass, landings and modelled biomass of TLs 2.5, 3.5 and 4.5 were considered over time, as representative of forage organisms, intermediate organisms and apex predators. Furthermore, the TL corresponding to the $95^{\text {th }}$ percentile of the distribution of biomass (TL ${ }_{95}$ h), landings and modelled biomass were tracked over time. TL ${ }_{95}$ th provided information about the trophic level of the apex predators accounting for the top $5 \%$ of landings or biomass (surveyed or modelled). Decreases in the $\mathrm{TL}_{95 \text { th }}$ can reflect a depletion of apex predators, which would be expected in the case of historical overfishing. Similarly to the pattern observed with $\mathrm{TL}_{\mathrm{L}}$, 'fishing further down' the food web would result in an increase of $\mathrm{TL}_{95}$ th as the relative contribution of low TL species decreases. Finally, the width of the trophic spectra was also estimated by the differences between TLs corresponding to the $5^{\text {th }}$ and $95^{\text {th }}$ percentiles of the TL distribution. In addition to the number of TLs present in the system, the width of the trophic spectra gave some insight into the part of the food web exploited by fisheries. Truncation of the trophic spectra, indicated by a decreasing width, could provide information about a change in trophic functioning if the signal is detected both in landings and survey indicators. On the other hand, an increase in the width of trophic spectra detected only in the landings might be evidence of fisheries expansion (i.e. 'fishing through').

\section{Implications of estimating TLs using different methods}

It is recognised that there is often uncertainty associated with allocating a single TL to a species. It is possible that TL changes seasonally or spatially depending on distributions of the prey and predator, demographic dynamics, climatic factors etc. (for example see Vinagre et al. 2012). Alternatively, different methods of estimating TLs may suggest different values for a species, thereby potentially influencing overall TL. For this reason, 2 methods were tested to derive MTL: (1) allowing TLs to vary annually (South Catalan Sea), and (2) using different TLs per species versus applying aggregated TLs per feeding guild (Southern Benguela). Overall, we found little difference between pairs of trends in each case (see Figs. S2 \& S3 in Supplement 3 at www.int-res.com/articles/suppl/m512 p115_supp.pdf). Nevertheless, model-derived TLs depend on how functional groups are aggregated and defined in trophic models. Models with more groups will often have higher TLs because they often define their higher TLs in greater detail, thereby imparting a compounding effect. Alternatively, TLs for species derived from isotope studies can differ from those estimated using trophic models that are based on weight of prey items in predators' stomachs (e.g. divergence of TL-related descriptors at high trophic levels; Van der Lingen \& Miller 2011) although they also may be well correlated (e.g. Coll et al. 2014). These discrepancies or similarities in TL estimations warrant further examination and refinement of both isotope studies (e.g. in base species used and factoring in detrital feeders) and model studies relying on limited or outdated dietary information. The discrepancies between stable isotopes and food web models have been tested by Ramsvatn (2013), who found that uncertainty in models can be reduced when using both stable isotope and diet studies, but both depend on previous knowledge of the diets of the species.

\section{RESULTS AND DISCUSSION}

\section{Trophic level indicator series}

Trends in TL-based indicators across the 9 case studies are shown in Fig. 2. Of the significant correla- 


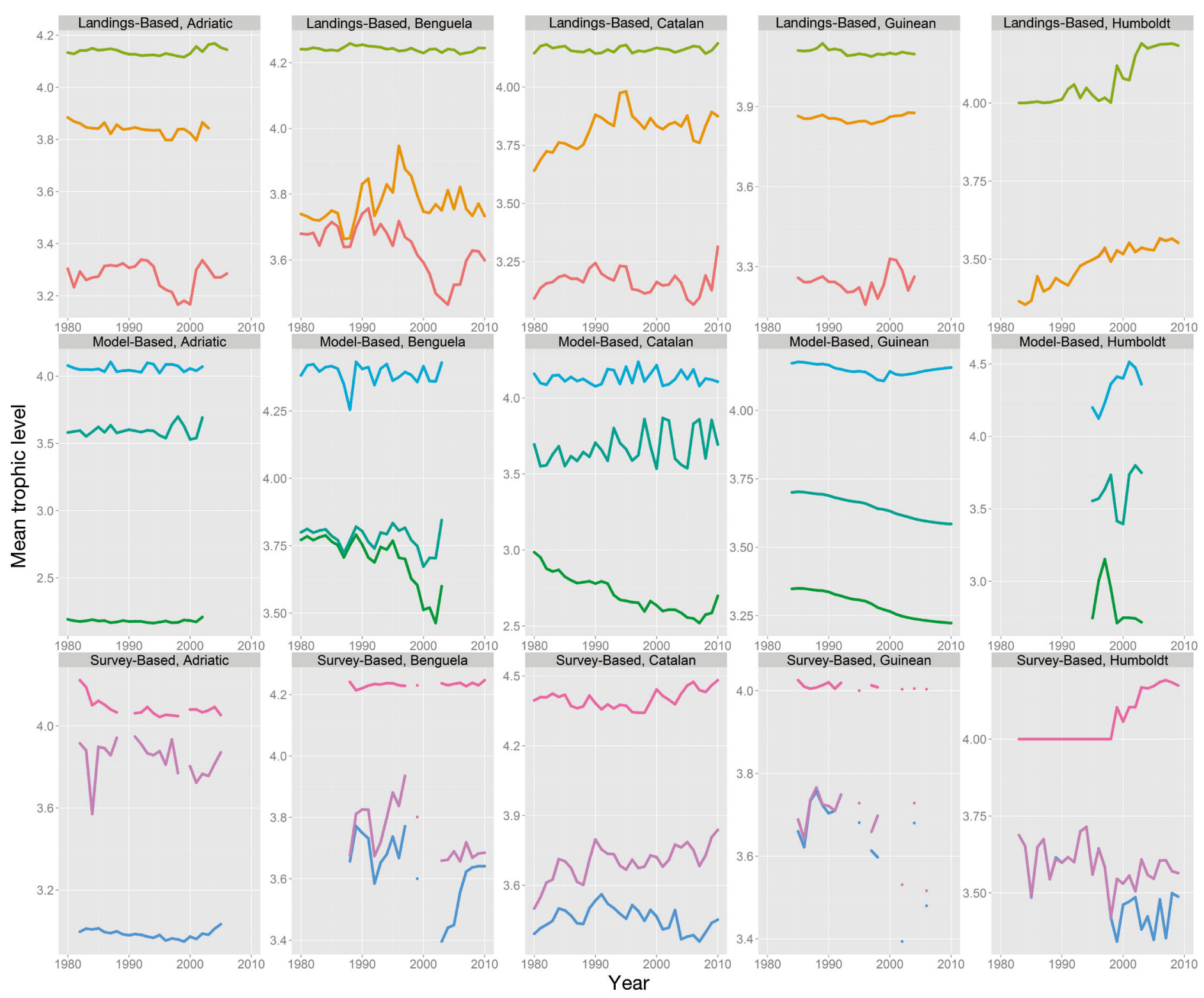

Fig. 2. Comparing trajectories of 9 trophic level (TL)-based indicators across the 9 ecosystem case studies. See Table 2 for definitions of the indicators. (Figure continued on next page)

tions $(\mathrm{p}<0.05)$ of these indicators with time $(\mathrm{yr}), 57 \%$ were negative (decline in TL with time, Table 3). Overall, some consistency was found within ecosystems between the 9 different TL-based indicators: the majority of significant correlations $(p<0.05)$ between pairs of TL-based indicators were positive (91 significantly positive correlations versus 31 significantly negative correlations; Table 3). Case study details (ecosystem description, model description, TL-based indicator interpretation) and correlation results are provided in Supplements 1 and 4, respectively, at www.int-res.com/articles/suppl/m512p115_ supp.pdf.
Comparison of $\mathrm{TL}_{\mathrm{L}}$ results with other indicators

In most ecosystems, $\mathrm{TL}_{\mathrm{L}}$ was positively related to various other TL-based indicators - although in one ecosystem, the North Central Adriatic, none of these were significant (Table 4a). Positive correlations were especially observed with $\mathrm{MTI}_{3.25}$ in 5 ecosystems (Tables $3 \& 4 a$ ), mainly due to the fact that species with TLs higher than 3.25 constitute a large fraction of the total landings. Catch-based and survey-based indicators were positively correlated in some ecosystems. $\mathrm{TL}_{\mathrm{SC}}$ was significantly positively correlated with $\mathrm{TL}_{\mathrm{L}}$ in 3 of the 9 ecosystems considered (Southern Benguela, 


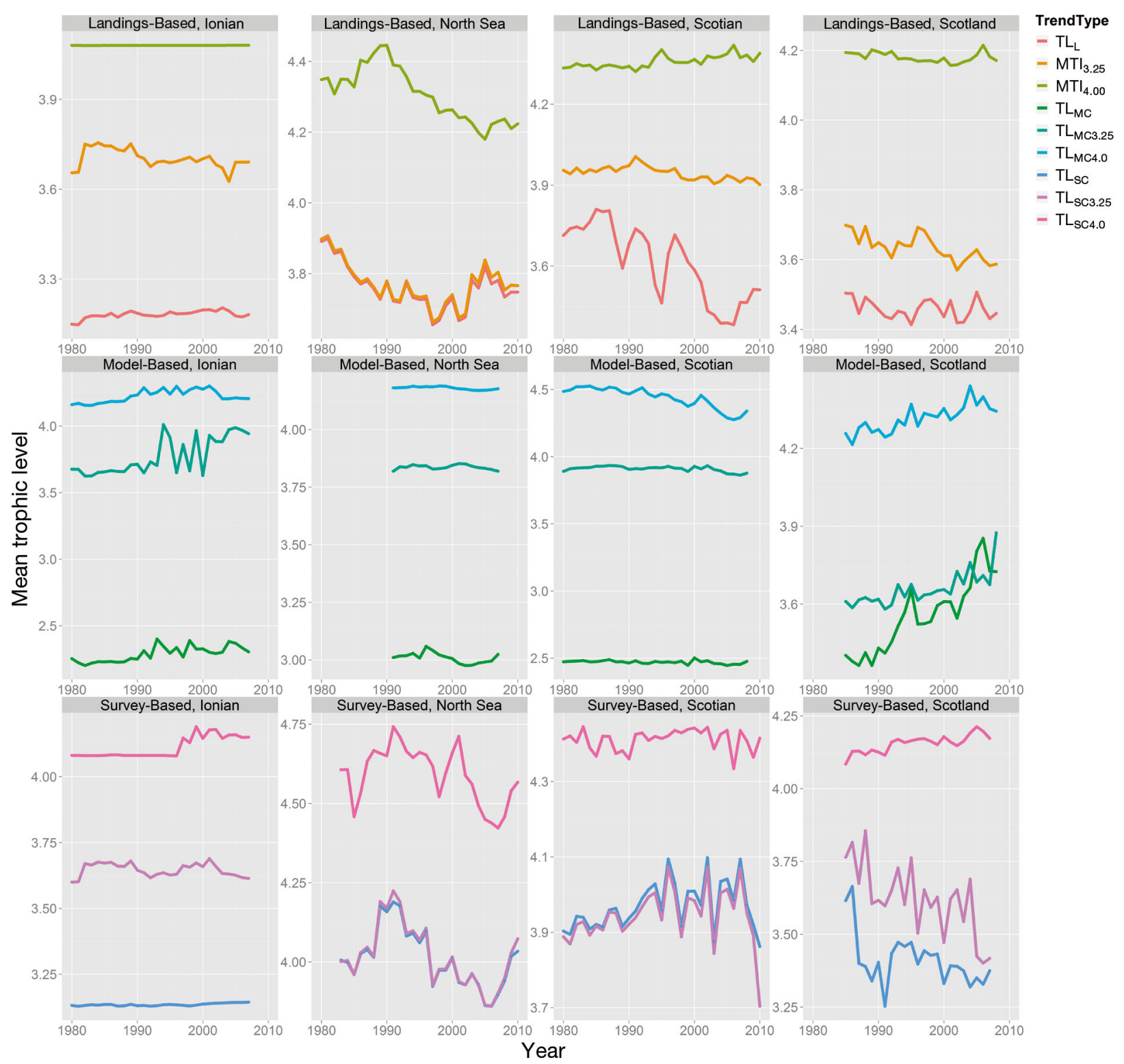

Fig. 2 (continued)

South Catalan Sea, Inner Ionian Sea; Tables 3 \& 4a). Similarly, $\mathrm{MTI}_{3.25}$ and $\mathrm{TL}_{\mathrm{SC} 3.25}$ were positively correlated in these same ecosystems as well as on the West Coast of Scotland (Table 4b).

However, despite general global agreement between $\mathrm{TL}_{\mathrm{L}}$ and other TL-based indicators (top row, Table 4a), survey-based TL indicators captured different effects to those captured by catch-based TL indicators in other ecosystems (Fig. 2), suggesting that both catch-based and survey-based indicators appear to be necessary to disentangle changes in community structure in several ecosystems. For example, in 2 ecosystems (Northern Humboldt and Western Scotian Shelf), $\mathrm{TL}_{\mathrm{L}}$ and $\mathrm{TL}_{\mathrm{SC}}$ were signifi- cantly negatively correlated (Table 4a). In the Northern Humboldt, landings were dominated by sardine Sardinops sagax and anchovy Engraulis ringens, whereas higher TL species such as Jack mackerel Trachurus murphyi $(\mathrm{TL}=3.9$ ) and chub mackerel Scomber japonicas $(\mathrm{TL}=3.7)$, which constituted an important part of fish biomass in the ecosystem before the El Niño in 1997-98, were included in the surveyed community. On the other hand, fished predators such as hake Merluccius gayi and jumbo squid Dosidicus gigas accounted for the increase in $\mathrm{MTI}_{4.0}$ and $\mathrm{TL}_{\mathrm{SC} 4.0}$ over the last decade.

On the Western Scotian Shelf, $\mathrm{TL}_{\mathrm{L}}$ has declined since the mid-1980s (Fig. 2) due to large declines in 
Table 3. Comparison of correlations between pairs of trophic level (TL)-based indicators across the 9 ecosystem case studies. Numbers indicate significant negative and positive correlations, separated by semi-colons. See Table 2 for definitions of TL-based indicators

\begin{tabular}{|c|c|c|c|c|c|c|c|c|c|c|}
\hline & Year & $\mathrm{TL}_{\mathrm{L}}$ & $\mathrm{MTI}_{3.25}$ & $\mathrm{MTI}_{4.0}$ & $\mathrm{TL}_{\mathrm{SC}}$ & $\mathrm{TL}_{\mathrm{SC} 3.25}$ & $\mathrm{TL}_{\mathrm{SC} 4.0}$ & $\mathrm{TL}_{\mathrm{MC}}$ & $\mathrm{TL}_{\mathrm{MC} 3.25}$ & $\mathrm{TL}_{\mathrm{MC4} .0}$ \\
\hline \multicolumn{11}{|l|}{ Year } \\
\hline $\mathrm{TL}_{\mathrm{L}}$ & $3 ; 2$ & & & & & & & & & \\
\hline $\mathrm{MTI}_{3.25}$ & $4 ; 3$ & $0 ; 5$ & & & & & & & & \\
\hline $\mathrm{MTI}_{4.0}$ & $3 ; 3$ & $1 ; 4$ & $1 ; 2$ & & & & & & & \\
\hline $\mathrm{TL}_{\mathrm{SC}}$ & $4 ; 2$ & $2 ; 3$ & $1 ; 3$ & $1 ; 6$ & & & & & & \\
\hline $\mathrm{TL}_{\mathrm{SC} 3.25}$ & $3 ; 1$ & $0 ; 1$ & $0 ; 4$ & $0 ; 1$ & $0 ; 6$ & & & & & \\
\hline $\mathrm{TL}_{\mathrm{SC} 4.0}$ & $2 ; 4$ & $1 ; 2$ & $3 ; 1$ & $0 ; 5$ & $2 ; 4$ & $2 ; 3$ & & & & \\
\hline $\mathrm{TL}_{\mathrm{MC}}$ & $4 ; 2$ & $0 ; 3$ & $4 ; 1$ & $1 ; 3$ & $0 ; 3$ & $2 ; 0$ & $1 ; 2$ & & & \\
\hline $\mathrm{TL}_{\mathrm{MC} 3.25}$ & $2 ; 2$ & $0 ; 1$ & $2 ; 1$ & $1 ; 2$ & $0 ; 1$ & $0 ; 0$ & $0 ; 2$ & $0 ; 5$ & & \\
\hline $\mathrm{TL}_{\mathrm{MC} .0}$ & $3 ; 3$ & $1 ; 2$ & $2 ; 1$ & $1 ; 2$ & $1 ; 1$ & $1 ; 1$ & $0 ; 1$ & $0 ; 5$ & $0 ; 4$ & \\
\hline
\end{tabular}

Table 4. Comparison of correlations of (a) $\mathrm{TL}_{\mathrm{L}}$ (b) $\mathrm{MTI}_{3.25}$ and (c) $\mathrm{TL}_{\mathrm{SC} 3.25}$ with the other TL-based indicators across the 9 case studies, and when all pairs of data are combined assuming equal weighting per pair (global). Values are correlation coefficients. Bold values in shaded cells indicate significant $(p<0.05)$ correlations: dark grey $=$ positive, light grey $=$ negative. See Table 2 for definitions of TL-based indicators

\begin{tabular}{|c|c|c|c|c|c|c|c|c|}
\hline (a) $\mathrm{TL}_{\mathrm{L}}$ & $\mathrm{MTI}_{3.25}$ & $\mathrm{MTI}_{4.0}$ & $\mathrm{TL}_{\mathrm{SC}}$ & $\mathrm{TL}_{\mathrm{SC} 3.25}$ & $\mathrm{TL}_{\mathrm{SC} 4.0}$ & $\mathrm{TL}_{\mathrm{MC}}$ & $\mathrm{TL}_{\mathrm{MC} 3.25}$ & $\mathrm{TL}_{\mathrm{MC} 4.0}$ \\
\hline Global & 0.06 & 0.70 & 0.68 & 0.46 & 0.41 & 0.41 & 0.40 & 0.61 \\
\hline NC Adriatic Sea & 0.21 & 0.16 & 0.25 & 0.20 & 0.24 & -0.04 & 0.10 & -0.08 \\
\hline S Benguela & 0.08 & 0.37 & 0.80 & 0.68 & -0.37 & 0.53 & 0.27 & 0.37 \\
\hline S Catalan Sea & 0.25 & 0.04 & 0.55 & 0.20 & -0.11 & 0.36 & -0.15 & -0.13 \\
\hline Guinean EEZ & 0.70 & 0.46 & 0.04 & -0.06 & 0.04 & -0.02 & -0.02 & 0.22 \\
\hline Inner Ionian Sea & -0.04 & 0.40 & 0.42 & 0.33 & 0.49 & 0.34 & 0.26 & 0.53 \\
\hline Northern Humboldt & 1.00 & 0.87 & -0.63 & -0.29 & 0.84 & -0.28 & 0.37 & 0.45 \\
\hline N Sea & 0.99 & 0.11 & -0.14 & -0.15 & -0.42 & -0.15 & -0.17 & -0.48 \\
\hline W Coast Scotland & 0.61 & 0.13 & 0.18 & 0.14 & -0.14 & -0.25 & -0.28 & -0.24 \\
\hline W Scotian Shelf & 0.65 & -0.79 & -0.37 & -0.29 & -0.04 & 0.48 & 0.47 & 0.86 \\
\hline (b) $\mathrm{MTI}_{3.25}$ & $\mathrm{TL}_{\mathrm{L}}$ & $\mathrm{MTI}_{4.0}$ & $\mathrm{TL}_{\mathrm{SC}}$ & $\mathrm{TL}_{\mathrm{SC} 3.25}$ & $\mathrm{TL}_{\mathrm{SC} 4.0}$ & $\mathrm{TL}_{\mathrm{MC}}$ & $\mathrm{TL}_{\mathrm{MC} 3.25}$ & $\mathrm{TL}_{\mathrm{MC} 4.0}$ \\
\hline Global & 0.06 & 0.40 & 0.30 & 0.65 & 0.39 & -0.30 & 0.20 & -0.06 \\
\hline NC Adriatic Sea & 0.21 & 0.23 & 0.67 & 0.26 & 0.37 & 0.56 & 0.06 & -0.23 \\
\hline S Benguela & 0.08 & -0.17 & 0.35 & 0.56 & -0.47 & -0.43 & 0.11 & 0.04 \\
\hline S Catalan Sea & 0.25 & -0.10 & 0.39 & 0.64 & -0.09 & -0.48 & 0.18 & 0.01 \\
\hline Guinean EEZ & 0.70 & 0.53 & 0.15 & 0.10 & 0.03 & -0.17 & -0.17 & 0.18 \\
\hline Inner Ionian Sea & -0.04 & -0.22 & -0.16 & 0.80 & -0.24 & -0.46 & -0.57 & -0.18 \\
\hline Northern Humboldt & 1.00 & 0.87 & -0.64 & -0.29 & 0.84 & -0.28 & 0.37 & 0.45 \\
\hline N Sea & 0.99 & 0.04 & -0.20 & -0.21 & -0.46 & -0.18 & -0.18 & -0.53 \\
\hline W Coast Scotland & 0.61 & 0.14 & 0.56 & 0.50 & -0.43 & -0.64 & -0.61 & -0.52 \\
\hline W Scotian Shelf & 0.65 & -0.62 & -0.06 & 0.02 & -0.17 & 0.25 & 0.38 & 0.70 \\
\hline (c) $\mathrm{TL}_{\mathrm{SC} 3.25}$ & $\mathrm{TL}_{\mathrm{L}}$ & $\mathrm{MTI}_{3.25}$ & $\mathrm{MTI}_{4.0}$ & $\mathrm{TL}_{\mathrm{SC}}$ & $\mathrm{TL}_{\mathrm{SC} 4.0}$ & $\mathrm{TL}_{\mathrm{MC}}$ & $\mathrm{TL}_{\mathrm{MC} 3.25}$ & $\mathrm{TL}_{\mathrm{MC} 4.0}$ \\
\hline Global & 0.46 & 0.65 & 0.63 & 0.59 & 0.59 & -0.17 & 0.40 & 0.07 \\
\hline NC Adriatic Sea & 0.20 & 0.26 & -0.30 & 0.25 & -0.03 & -0.22 & 0.09 & -0.31 \\
\hline S Benguela & 0.68 & 0.56 & 0.25 & 0.81 & -0.55 & 0.33 & 0.32 & -0.03 \\
\hline S Catalan Sea & 0.20 & 0.64 & -0.13 & 0.27 & 0.36 & -0.48 & 0.09 & 0.04 \\
\hline Guinean EEZ & -0.06 & 0.10 & 0.41 & 0.89 & 0.11 & 0.27 & 0.27 & 0.19 \\
\hline Inner Ionian Sea & 0.33 & 0.80 & -0.18 & 0.03 & 0.13 & -0.35 & -0.31 & 0.01 \\
\hline Northern Humboldt & -0.29 & -0.29 & -0.24 & 0.76 & -0.31 & 0.17 & -0.03 & -0.65 \\
\hline N Sea & -0.15 & -0.21 & 0.69 & 1.00 & 0.69 & 0.39 & 0.27 & 0.58 \\
\hline W Coast Scotland & 0.14 & 0.50 & -0.07 & 0.56 & -0.52 & -0.51 & -0.23 & -0.32 \\
\hline W Scotian Shelf & -0.29 & 0.02 & 0.34 & 0.98 & 0.48 & -0.30 & -0.03 & -0.45 \\
\hline
\end{tabular}


the catches of traditional groundfish species such as cod Gadus morhua, pollock Pollachius virens and haddock Melanogrammus aeglefinus, and herring Clupea harengus $(\mathrm{TL}=3.87)$. At the same time, there has been an increase in invertebrates, mostly scallop Placopecten magellanicus $(\mathrm{TL}=2.05)$ and lobster Homarus americanus ( $\mathrm{TL}=3.1$ ) in the catch, from around $5 \%$ of the total catch in the mid-1980s to around $25 \%$ of the catch in the late 2000s. In contrast, $\mathrm{MTI}_{4.0}$ has increased despite the declining total catch, since catches of non-traditional species such as spiny dogfish Squalus acanthias and large pelagics have increased, and the relative catches of other predators such as Atlantic halibut Hippoglossus hippoglossus and the demersal piscivores have also increased. Despite the decline in groundfish stocks on the Western Scotian Shelf, there is an increasing trend in $\mathrm{TL}_{\mathrm{SC}}$. The decline in groundfish abundance was masked by the decline in herring and the increase in dogfish, both contributing to an increasing $\mathrm{TL}_{\mathrm{SC}}$. Although dogfish are caught commercially, catches are relatively low and not a good indicator of abundance since there has been a quota of $2500 \mathrm{t}$ since 2004 (DFO 2007).

\section{Comparison of model-based TL results with other indicators}

No significant negative correlations were found between $\mathrm{TL}_{\mathrm{SC}}$ and $\mathrm{TL}_{\mathrm{MC}}$, $\mathrm{TL}_{\mathrm{SC} 3.25}$ and $\mathrm{TL}_{\mathrm{MC} 3.25}$ or $\mathrm{TL}_{\mathrm{SC} 4.0}$ and $\mathrm{TL}_{\mathrm{MC} 4.0}$ but strong positive correlations in these 3 pairs were also few (Table 3). In 3 of the 9 ecosystems, $\mathrm{TL}_{\mathrm{SC}}$ and $\mathrm{TL}_{\mathrm{MC}}$ were significantly positively correlated (Southern Benguela, Catalan Sea and Northern Humboldt), whereas in the West Coast of Scotland $\mathrm{TL}_{\mathrm{SC} 4.0}$ and $\mathrm{TL}_{\mathrm{MC} 4.0}$ were significantly positively correlated (see Table S4 in Supplement 4 at www.int-res.com/articles/suppl/m512p115_supp. pdf). $\mathrm{TL}_{\mathrm{SC} 3.25}$ and $\mathrm{TL}_{\mathrm{MC} 3.25}$ were not significantly correlated in any of the ecosystems (Tables $3 \& 4 \mathrm{c}$, and Table S4). The sparsity of significant positive correlations between survey-based and model-based indicator pairs indicates that there is no clear commonality between the representation of community structure by the survey-based and model-based indicators.

In the North Sea, $\mathrm{TL}_{\mathrm{MC4.0}}$ differed from $\mathrm{TL}_{\mathrm{MC} 3.25}$ due to the high abundance of sandeels Ammodytes marinus in $\mathrm{TL}_{\mathrm{MC} 3.25}$ (Fig. 2, Table S4). When this species was removed from $\mathrm{TL}_{\mathrm{MC} 3.25}$, the correlation between indicators was high $(\mathrm{R}=0.89$, data not shown). The model-based indicators also differed from the survey-based indicators due to the different species that were accounted for in each indicator, and differing proportions of species that were common to both indicators. Relative proportions can differ due to unknown survey catchabilities. The demersal survey (International Bottom Trawl Survey during quarter 1 ) does not record many sandeel $(\mathrm{TL}=$ 3.1) or sole Solea solea (TL $=4.2$ ) due to a very low catchability in the survey gear but does catch numerous dab Limanda limanda $(\mathrm{TL}=4.2)$ and herring $C$. harengus $(\mathrm{TL}=3.8)$, albeit with unknown catchability. The difference between $\mathrm{TL}_{\mathrm{MC} 3.25}$ and $\mathrm{TL}_{\mathrm{SC} 3.25}$ was due to a high abundance of sandeels in the model: removing sandeels from the dataset increased the correlation between indicators from $0.27(p=0.29)$ to $0.62(p<0.01)$. A non-significant correlation was found between $\mathrm{TL}_{\mathrm{MC} 4.0}$ and $\mathrm{TL}_{\mathrm{SC} 4.0}$. Much of the difference here was due to whiting Merlangius merlangus (TL > 4), since they were the dominant group by catch-rate in the survey but not in the model: for example, the catch-rate of whiting in the survey was 4 times that of cod despite similar average biomasses for these species in the model. Despite a good correlation between the model biomass and the survey catch rate for this species $(\mathrm{R}=0.69, \mathrm{df}=15, \mathrm{p}<0.01)$, simply by removing whiting from the dataset, the correlation between the indicators increased from 0.34 $(p=0.19)$ to $0.60(p=0.01)$. Hence, differences between indicators could merely have been a result of different data treatment, and thus relative weighting of species within the dataset, rather than differences in underlying state.

In the case of the West Coast of Scotland, surveys suggested a degraded ecosystem whereas models were reflecting increases in other species (e.g. Nephrops norvegicus and top predators) and possibly even that there has been a regime shift in this ecosystem, specifically in the Clyde Sea (a subsection of the West Coast; Thurstan \& Roberts 2010, Howarth et al. 2013). Despite non-significant correlations between $\mathrm{TL}_{\mathrm{L}}$ and survey- and model-based $\mathrm{TL}$ indicators on the West Coast of Scotland (Table 4), survey-based TL indicators declined over time for $\mathrm{TL}_{\mathrm{SC}}$ and $\mathrm{TL}_{\mathrm{SC} 3.25}$, as did catch-based TL indicators for this ecosystem (Fig. 2). The increase in the $\mathrm{TL}_{\mathrm{SC} 4.0}$ since 2000 reflects the decline in abundance of cod G. morhua ( $\mathrm{TL}=3.96$ for adults) and haddock $M$. aeglefinus ( $\mathrm{TL}=3.7$ ) (Heath \& Speirs 2012) and an increase in large demersal species $(\mathrm{TL}=4.3)$ and sharks $(\mathrm{TL}=4.1$ ). The decline in other survey-based indicators reflects the large increases in mackerel $(\mathrm{TL}=3.3)$ and haddock $(\mathrm{TL}=3.7)$ biomass in surveys (see also Fig. 3). However, biomass of large predators 
Biomass of particular TLs (Survey)
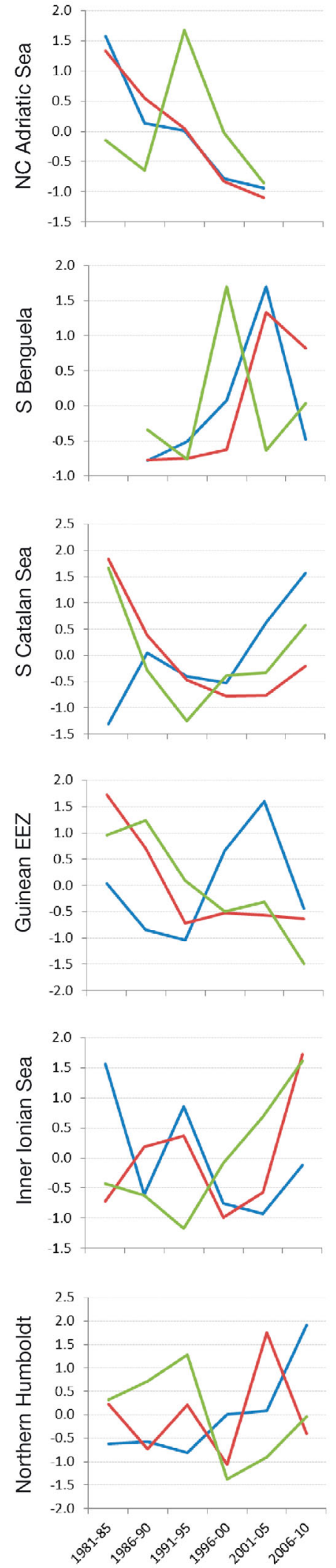
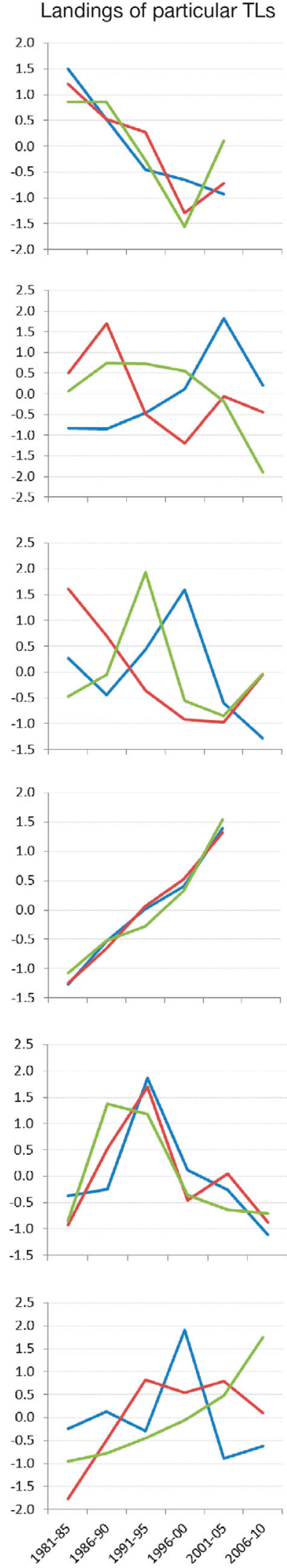

Biomass of particular TLs (Model)
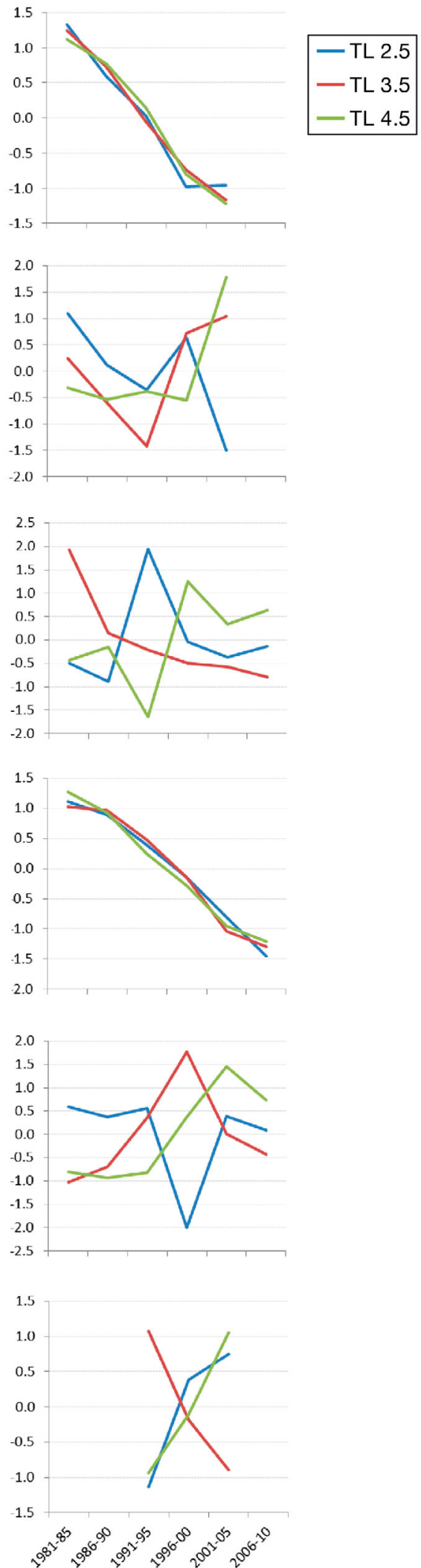

Fig. 3. Trophic spectra of evolution over time for TL 2.5, 3.5 and 4.5 in the survey, catch and model data. (Figure continued on next page) 
Biomass of particular TLs (Survey)
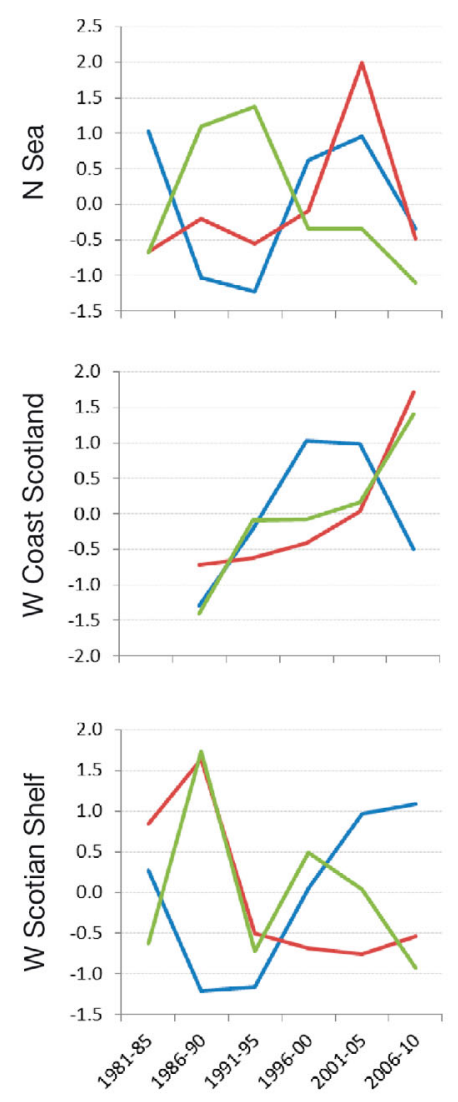

Landings of particular TLs
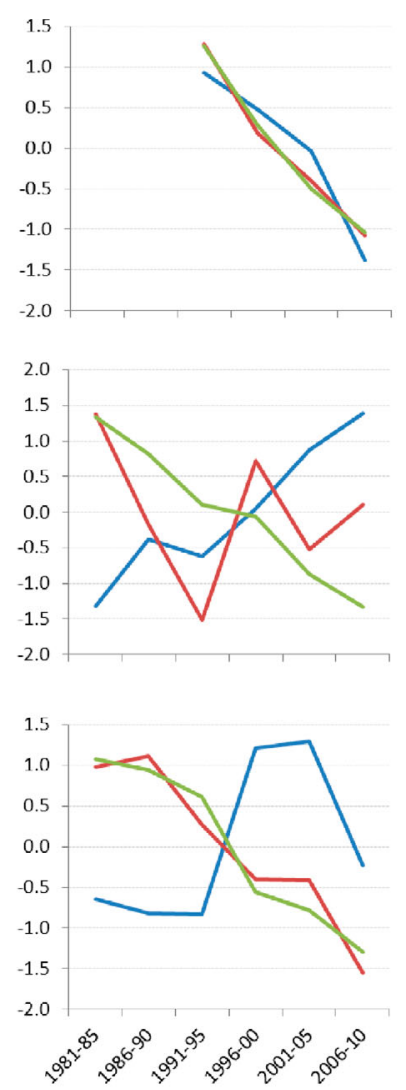

Fig. 3 (continued)
Biomass of particular TLs (Model)
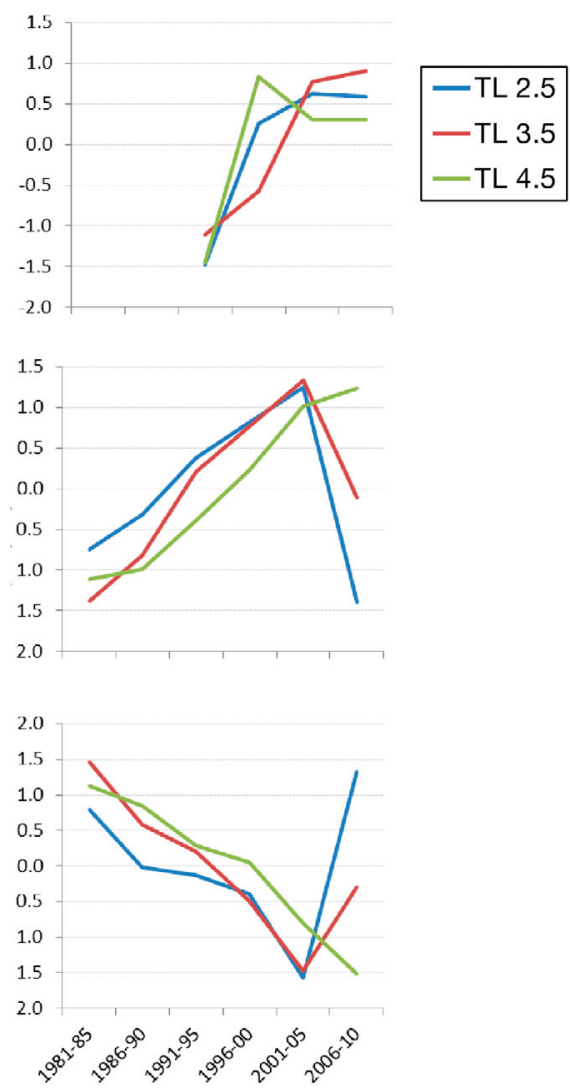

such as grey and harbour seals, and other species such as monkfish (Lophius piscatorius and L. Budegassa), flatfish (Pleuronectes platessa, Lepidorhombus whiffiagonis, Psetta maxima, halibut Hippoglossus hippoglossus, Scophthalmus rhombus, Hippoglossoides platessoides, Limanda limanda, Glyptocephalus cynoglossus, Platichthys flesus), rays (Dipturus batis, Raja clavata, R. brachyura, R. montagui, R. naevus, Rostroraja alba, Leucoraja circularis, L. fullonica, Amblyraja radiate), blue whiting (Micromesistius poutassou), small and large demersals have all increased both in catch per unit effort (CPUE) and in modelled biomass (Alexander 2012). Thus, although the main commercial species have declined off west Scotland, fishing drivers have decreased over time (Fig. 4) and the biomass (and therefore $\mathrm{TL}_{\mathrm{MC}}$ Fig. 2) of non-commercially important species have shown increasing trends, reflecting changes in the community structure of the ecosystem from a mainly gadoiddominated ecosystem to one that is now mostly dominated by invertebrates. Thus, the cod recovery plan (instituted in 2002) had the effect of increasing the biomass of predators and competitors of cod, but not necessarily the biomass of cod itself.
In Guinea, the fishing pressure strongly increased over the studied period (Fig. 4) with a 7 -fold increase in fishing pressure between 1985 and 2005, leading to the overexploitation of many fish stocks, especially demersal coastal species (Gascuel et al. 2009b). During that time, landings tripled and were dominated by ethmalosa Ethmalosa fimbriata, followed by small pelagics (Sardinella aurita and horse mackerel Trachurus spp.), fish from the demersal sciaenid community (bobo croaker Pseudotolithus pseudotolithus, sea catfishes Arius sp.), and cephalopods (Octopus vulgaris). An increase in landings was observed for almost all species. Thus, landing-based TL indicators remained almost stable over the period, slightly decreasing during the first decade (due to a stronger increase in catch of low-TL species such as ethmalosa, sardinella or mullets) and increasing over the last years (notably due to an increase in landings of large pelagics). Surveyed biomass, referring to demersal finfish, decreased sharply over the whole period, from 500000 to 200000 t. The decline affected most groups but was especially strong for high TLs such as various species of croakers ( $\mathrm{TL}=3.92$ ) and giant African threadfin Polydactylus quadrifilis 


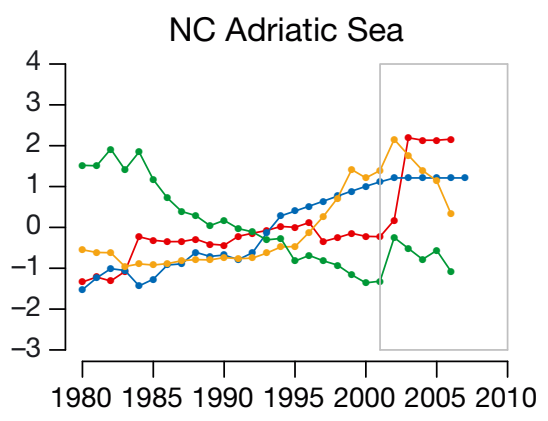

Guinean EEZ

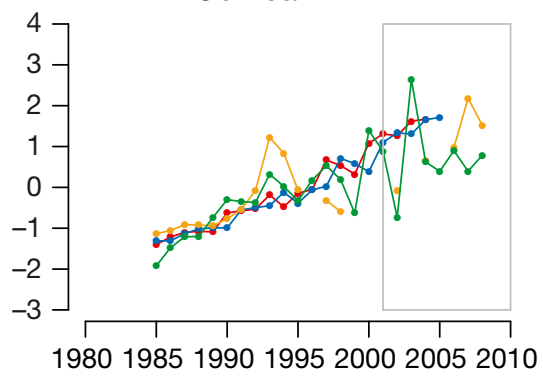

N Sea

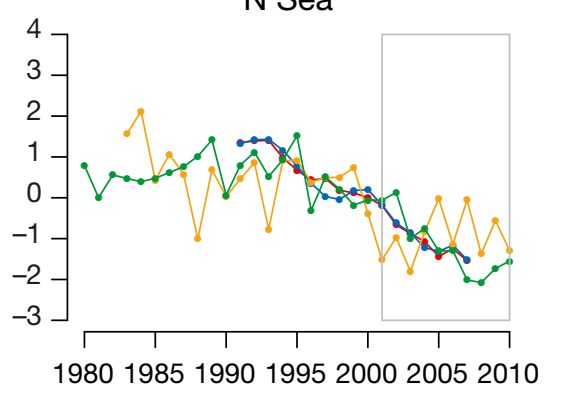

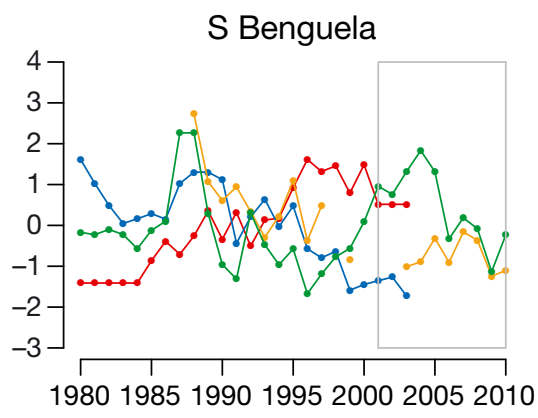

Inner Ionian Sea

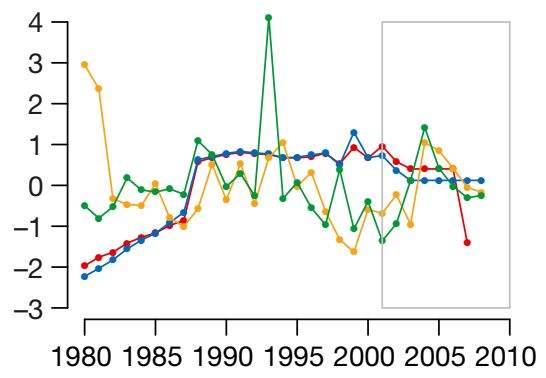

W Coast Scotland

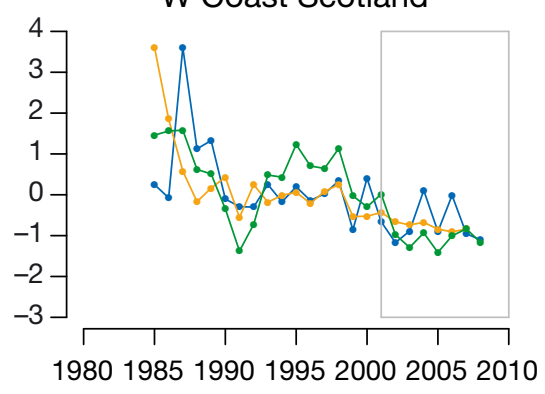

S Catalan Sea

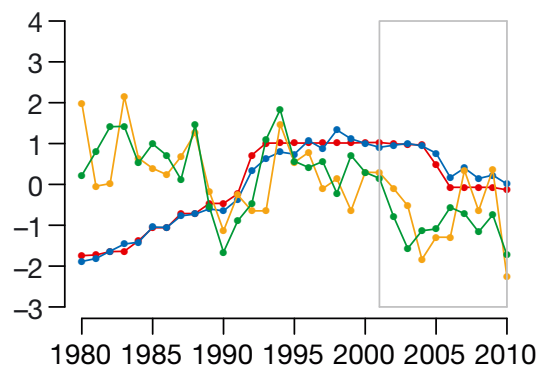

Northern Humboldt

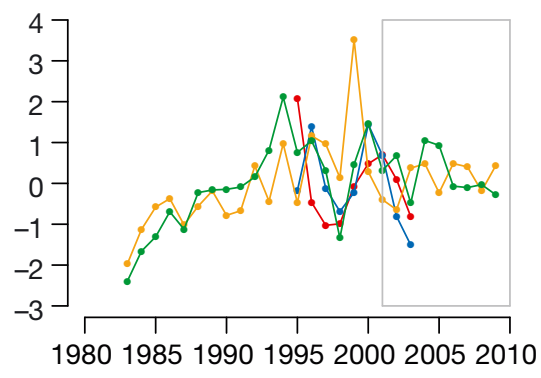

W Scotian Shelf

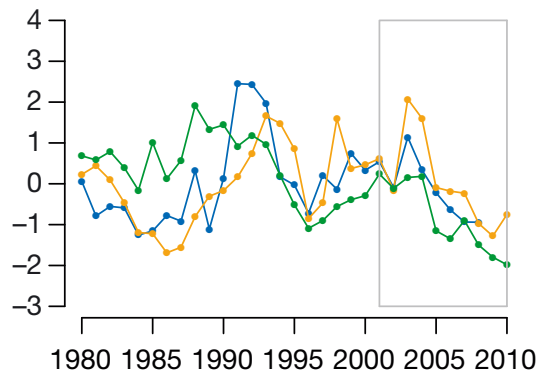

Fishing Effort

Fishing Mortality

$\because$ Landings/Biomass

$\multimap$ Landings

Fig. 4. Time series of fishing drivers across the 9 case studies: normalized fishing effort (relative summed fishing effort across model fisheries, used to drive the Ecopath with Ecosim [EwE] models), fishing mortality rate (summed across all fished model groups; output from EwE models), landings/biomass (from commercial and survey data), and landings. Trajectories of fishing drivers in the most recent decade are highlighted within the grey frames

$(\mathrm{TL}=4.11)$, and reached a 10 -fold decrease for bobo croakers $(\mathrm{TL}=3.91)$. Survey-based TL indicators decreased accordingly. The same declining trend was observed with respect to the biomass of the entire Guinean ecosystem. Trophic spectral analysis showed that the decrease in biomass was more accentuated for high-TL groups $(-25 \%$ for $\mathrm{TL}=3.0$ and $-50 \%$ for $\mathrm{TL} \geq 3.5$ ), leading to a decrease in model-based indicators (Figs. $2 \& 3$ ).

Our results highlight that ecosystems are complex, and landings or survey-based indicators only provide information on the parts of the ecosystem that they sample. We need additional information on nonsurveyed species, fishing drivers and environmental influences (see sections below) to interpret TL-based indicators. The absence of clear global patterns in correlation results for model- and survey-based TL indicators suggest that changes in non-surveyed species are important contributors to understanding what is happening at the ecosystem level. Models can often be useful in providing some of these necessary insights, as evidenced in the case study examples above.

\section{Relating trophic level-based indicators to fishing}

Modelled fishing effort increased significantly over time in 5 of the 7 ecosystems with available data (fishing effort was not provided for the West Coast of Scotland or Western Scotian Shelf), whereas a significant negative trend over time was found for the 
Table 5. Correlations of fishing drivers with time (year): fishing mortality (FM) output from Ecopath with Ecosim (EwE) models fitted to catch and abundance time series data; overall fishing effort (FE, relative summed fishing effort across model fisheries) based on inputs used to drive ecosystem dynamics in EwE models; actual landings (data) divided by biomass (survey data) (LtBs). Values are correlation coefficients. Bold values in shaded cells indicate significant $(\mathrm{p}<$ 0.05 ) correlations: dark grey $=$ positive, light grey $=$ negative

\begin{tabular}{|lrrrr|}
\hline & FE & FM & LtBs & Landings \\
\hline Global & 0.15 & 0.02 & 0.11 & -0.02 \\
NC Adriatic Sea & $\mathbf{0 . 8 4}$ & $\mathbf{0 . 9 8}$ & $\mathbf{0 . 8 1}$ & $\mathbf{- 0 . 8 8}$ \\
S Benguela & $\mathbf{0 . 8 6}$ & $\mathbf{- 0 . 7 7}$ & $\mathbf{- 0 . 8 1}$ & 0.04 \\
S Catalan Sea & $\mathbf{0 . 6 2}$ & $\mathbf{0 . 6 8}$ & $\mathbf{- 0 . 4 9}$ & $\mathbf{- 0 . 6 4}$ \\
Guinean EEZ & $\mathbf{0 . 9 9}$ & $\mathbf{0 . 9 9}$ & $\mathbf{0 . 8 6}$ & $\mathbf{0 . 7 9}$ \\
Inner Ionian Sea & $\mathbf{0 . 3 9}$ & $\mathbf{0 . 3 6}$ & -0.08 & 0.01 \\
Northern Humboldt & 0.02 & -0.43 & $\mathbf{0 . 5 8}$ & $\mathbf{0 . 4 5}$ \\
N Sea & $\mathbf{- 0 . 9 9}$ & $\mathbf{- 0 . 9 6}$ & $\mathbf{- 0 . 6 9}$ & $\mathbf{- 0 . 7 2}$ \\
W Coast Scotland & NA & $\mathbf{- 0 . 5 9}$ & $\mathbf{- 0 . 8 6}$ & $\mathbf{- 0 . 6 7}$ \\
W Scotian Shelf & NA & 0.21 & 0.11 & $\mathbf{- 0 . 7 3}$ \\
\hline
\end{tabular}

North Sea, and no significant trend occurred in the Northern Humboldt (Table 5). Mixed trends emerged for fishing mortality. Fisheries drivers used in or derived from models (fishing effort, fishing mortality, landings/biomass) and landings followed similar trajectories over time in the North Sea, Guinean exclusive economic zone (EEZ), West Coast of Scotland, Western Scotian Shelf, Inner Ionian Sea and Northern Humboldt ecosystems, whereas diverse trajectories were observed in the other 3 ecosystems (Table 5, Fig. 4).

Knowledge of the exploitation history and fisheries management strategies adopted in an ecosystem is vital for interpreting TL-based indicator trajectories. For example, fishing drivers and landings declined over time in the North Sea and West Coast of Scotland, reflecting active fisheries management in these ecosystems, whereas they strongly increased off Guinea, capturing expansion of fisheries there (Table 5, Fig. 4). After the 1990s, fishing effort, pressure and landings declined off the Western Scotian Shelf, due to fisheries management measures in response to large declines in cod and other groundfish stocks. In the Mediterranean ecosystems (North Central Adriatic, South Catalan Sea and Inner Ionian Sea), at least 2 fishing drivers increased over time whereas landings declined, suggesting depletion of these ecosystems (Coll et al. 2008, 2009, 2010a, Piroddi et al. 2010). In the Northern Humboldt, fishing pressure and landings increased, whereas the shorter fishing effort and mortality trajectories had no overall trend, but were comparable for common years. The Southern Benguela system was more complicated. Fishing effort increased whereas fishing mortality and pressure declined, and landings fluctuated. Thus for the Southern Benguela, TL-based indicator trajectories may not be easy to interpret with respect to fisheries trajectories. This is further confounded by the important role of environmental drivers in upwelling systems (Shannon et al. 2008); environmental perturbations and related large fluctuations in low TLs in upwelling systems should be borne in mind when assessing fishing effects. The Southern Benguela (see Supplement 1 for details) could be viewed as showing some of the signs of a system that has been 'fished down' ( $\mathrm{TL}_{\mathrm{L}}$ and $\mathrm{MTI}_{4.0}$ and catch of species with TL $>4.0$ have all declined over time). However, the situation has been complicated by the unusual upsurge in small pelagic fish in the early 2000s. Pooling data from all 9 case studies showed that several TL-based indicators were negatively correlated with fishing mortality, landings/biomass, and landings (Table 6). However, this pattern is not consistent for the individual ecosystems. For example, on the global scale, $\mathrm{TL}_{\mathrm{MC}}$ was not significantly related to fishing effort, but individual ecosystems exhibited positive and negative correlations between $\mathrm{TL}_{\mathrm{MC}}$ and fishing effort. Again, at the global scale, $\mathrm{TL}_{\mathrm{MC}}$ was negatively correlated with model fishing mortality and positively correlated with fishing pressure (Table 6 ), but at the ecosystem level, $\mathrm{TL}_{\mathrm{MC}}$ and fishing pressure were positively correlated in 3 ecosystems and negatively correlated in 2 ecosystems. Significant negative correlations were found between $\mathrm{TL}_{\mathrm{MC} .25}$ and fishing pressure as well as fishing mortality when all ecosystems were combined. The wide range of response of TL-based indicators to fishing drivers highlights the complexity of ecosystems and the importance of additional information and a deep understanding of an ecosystem's dynamics to interpret TL-based indicators. Notably, by pooling data (as is done in meta-analyses), this individual variation in response was masked, suggesting a more consistent response across ecosystems than actually exists.

There were no consistent changes in fishing pressure and effort across ecosystems (Table 5, Fig. 4). However, some interesting patterns emerged at the ecosystem scale. MTI $_{3.25}$ declined in the North Central Adriatic, Inner Ionian Sea, North Sea, West Coast of Scotland and the Western Scotian Shelf (Fig. 2, Table S4 in Supplement 4: negative correlations with year are all significant apart from the weaker trend for the North Sea). In all of these ecosystems, landings of species at TL 4.5 also decreased (Fig. 3). On the West Coast of Scotland, $\mathrm{TL}_{\mathrm{SC} 4.0}$ and $\mathrm{TL}_{\mathrm{MC} 4.0}$ increased over the full time period examined, and 
Table 6. Correlations between trophic level (TL) indicators and fishing drivers: (a) model fishing effort, (b) model fishing mortality, (c) fishing pressure (landings/biomass), and (d) landings. Values are correlation coefficients. Bold values in shaded cells indicate significant $(p<0.05)$ correlations: dark grey = positive, light grey = negative. See Table 2 for definitions of the

TL-based indicators. Fishing effort data was not provided for the West Coast of Scotland and Western Scotian Shelf

\begin{tabular}{|c|c|c|c|c|c|c|c|c|c|}
\hline (a) Fishing effort & $\mathrm{TL}_{\mathrm{L}}$ & $\mathrm{MTI}_{3.25}$ & $\mathrm{MTI}_{4.0}$ & $\mathrm{TL}_{\mathrm{SC}}$ & $\mathrm{TL}_{\mathrm{SC} 3.25}$ & $\mathrm{TL}_{\mathrm{SC} 4.0}$ & $\mathrm{TL}_{\mathrm{MC}}$ & $\mathrm{TL}_{\mathrm{MC} 3.25}$ & $\mathrm{TL}_{\mathrm{MC} 4.0}$ \\
\hline Global & -0.32 & 0.23 & 0.00 & -0.12 & -0.18 & 0.03 & 0.10 & 0.08 & 0.24 \\
\hline NC Adriatic Sea & 0.02 & -0.37 & 0.10 & -0.14 & -0.42 & -0.46 & -0.14 & -0.01 & -0.02 \\
\hline S Benguela & -0.29 & 0.72 & -0.25 & 0.22 & 0.59 & -0.16 & -0.69 & -0.14 & -0.19 \\
\hline S Catalan Sea & -0.12 & 0.62 & -0.09 & 0.11 & 0.27 & -0.20 & -0.69 & 0.25 & 0.19 \\
\hline Guinean EEZ & 0.01 & 0.14 & -0.58 & -0.40 & -0.07 & -0.43 & -0.99 & -0.99 & -0.87 \\
\hline Inner Ionian Sea & 0.51 & -0.03 & 0.34 & -0.09 & 0.17 & 0.26 & 0.47 & 0.27 & 0.86 \\
\hline Northern Humboldt & -0.03 & -0.03 & 0.27 & 0.05 & -0.15 & 0.19 & -0.38 & -0.23 & 0.32 \\
\hline N Sea & -0.39 & -0.46 & 0.95 & 0.84 & 0.86 & 0.80 & 0.50 & 0.14 & 0.66 \\
\hline \multicolumn{10}{|l|}{$\begin{array}{l}\text { W Coast Scotland } \\
\text { W Scotian Shelf }\end{array}$} \\
\hline (b) Fishing mortality & $\mathrm{TL}_{\mathrm{L}}$ & $\mathrm{MTI}_{3.25}$ & $\mathrm{MTI}_{4.0}$ & $\mathrm{TL}_{\mathrm{SC}}$ & $\mathrm{TL}_{\mathrm{SC} 3.25}$ & $\mathrm{TL}_{\mathrm{SC} 4.0}$ & $\mathrm{TL}_{\mathrm{MC}}$ & $\mathrm{TL}_{\mathrm{MC} 3.25}$ & $\mathrm{TL}_{\mathrm{MC} 4.0}$ \\
\hline Global & -0.79 & 0.14 & -0.69 & -0.56 & -0.26 & -0.39 & -0.61 & -0.24 & -0.49 \\
\hline NC Adriatic Sea & -0.14 & -0.48 & 0.09 & -0.36 & -0.44 & -0.53 & -0.22 & 0.07 & 0.01 \\
\hline S Benguela & 0.45 & -0.47 & 0.64 & 0.37 & -0.05 & 0.03 & 0.77 & 0.26 & 0.02 \\
\hline S Catalan Sea & -0.21 & 0.61 & -0.14 & 0.08 & 0.37 & -0.15 & -0.74 & 0.19 & 0.12 \\
\hline Guinean EEZ & -0.01 & 0.15 & -0.56 & -0.41 & -0.08 & -0.42 & -0.99 & -0.99 & -0.87 \\
\hline Inner Ionian Sea & 0.48 & -0.07 & 0.36 & -0.13 & 0.05 & 0.21 & 0.48 & 0.24 & 0.84 \\
\hline Northern Humboldt & -0.08 & -0.08 & -0.43 & 0.47 & 0.20 & -0.47 & 0.58 & -0.63 & -0.15 \\
\hline N Sea & -0.30 & -0.36 & 0.96 & 0.89 & 0.91 & 0.84 & 0.44 & 0.23 & 0.63 \\
\hline W Coast Scotland & 0.27 & 0.60 & 0.35 & 0.11 & 0.37 & -0.17 & -0.50 & -0.33 & -0.19 \\
\hline W Scotian Shelf & -0.22 & 0.02 & -0.03 & 0.23 & 0.22 & 0.27 & -0.26 & -0.19 & -0.18 \\
\hline (c) Landings/biomass & $\mathrm{TL}_{\mathrm{L}}$ & $\mathrm{MTI}_{3.25}$ & $\mathrm{MTI}_{4.0}$ & $\mathrm{TL}_{\mathrm{SC}}$ & $\mathrm{TL}_{\mathrm{SC} 3.25}$ & $\mathrm{TL}_{\mathrm{SC} 4.0}$ & $\mathrm{TL}_{\mathrm{MC}}$ & $\mathrm{TL}_{\mathrm{MC} 3.25}$ & $\mathrm{TL}_{\mathrm{MC} 4.0}$ \\
\hline Global & 0.26 & -0.30 & 0.22 & 0.18 & 0.01 & 0.20 & 0.54 & -0.31 & -0.13 \\
\hline NC Adriatic Sea & -0.31 & -0.24 & -0.03 & -0.44 & -0.49 & -0.43 & -0.02 & 0.09 & 0.14 \\
\hline S Benguela & 0.60 & 0.07 & 0.55 & 0.67 & 0.54 & -0.26 & 0.76 & 0.02 & -0.18 \\
\hline S Catalan Sea & -0.05 & -0.32 & 0.05 & -0.03 & -0.69 & -0.23 & 0.37 & 0.05 & -0.09 \\
\hline Guinean EEZ & -0.41 & -0.39 & -0.65 & -0.33 & -0.10 & -0.61 & -0.86 & -0.86 & -0.59 \\
\hline Inner Ionian Sea & -0.43 & -0.40 & 0.20 & 0.11 & -0.57 & -0.28 & 0.18 & 0.20 & -0.09 \\
\hline Northern Humboldt & 0.65 & 0.65 & 0.53 & -0.35 & -0.09 & 0.36 & 0.12 & -0.45 & -0.33 \\
\hline N Sea & 0.02 & -0.01 & 0.55 & 0.41 & 0.39 & 0.18 & 0.64 & -0.13 & 0.74 \\
\hline W Coast Scotland & 0.27 & 0.69 & 0.32 & 0.70 & 0.57 & -0.61 & -0.78 & -0.71 & -0.69 \\
\hline W Scotian Shelf & -0.35 & -0.13 & 0.11 & 0.15 & 0.08 & 0.25 & -0.27 & -0.35 & -0.34 \\
\hline (d) Landings & $\mathrm{TL}_{\mathrm{L}}$ & $\mathrm{MTI}_{3.25}$ & $\mathrm{MTI}_{4.0}$ & $\mathrm{TL}_{\mathrm{SC}}$ & $\mathrm{TL}_{\mathrm{SC} 3.25}$ & $\mathrm{TL}_{\mathrm{SC} 4.0}$ & $\mathrm{TL}_{\mathrm{MC}}$ & $\mathrm{TL}_{\mathrm{MC} 3.25}$ & $\mathrm{TL}_{\mathrm{MC} 4.0}$ \\
\hline Global & 0.30 & -0.25 & 0.06 & 0.03 & -0.30 & -0.36 & 0.45 & -0.09 & 0.48 \\
\hline NC Adriatic Sea & 0.36 & 0.69 & 0.21 & 0.66 & 0.37 & 0.62 & 0.27 & 0.02 & 0.02 \\
\hline S Benguela & -0.53 & -0.59 & 0.00 & -0.59 & -0.68 & 0.31 & -0.14 & -0.35 & -0.18 \\
\hline S Catalan Sea & -0.06 & -0.37 & 0.27 & 0.13 & -0.69 & -0.35 & 0.53 & -0.12 & 0.16 \\
\hline Guinean EEZ & -0.15 & -0.04 & -0.58 & -0.38 & -0.17 & -0.27 & -0.79 & -0.79 & -0.52 \\
\hline Inner Ionian Sea & 0.04 & 0.08 & 0.27 & 0.05 & -0.13 & -0.13 & 0.22 & -0.03 & -0.20 \\
\hline Northern Humboldt & 0.44 & 0.44 & 0.48 & -0.15 & -0.12 & 0.22 & 0.03 & -0.57 & -0.13 \\
\hline N Sea & -0.11 & -0.17 & 0.78 & 0.59 & 0.57 & 0.65 & 0.28 & 0.25 & 0.57 \\
\hline W Coast Scotland & 0.32 & 0.75 & 0.04 & 0.68 & 0.56 & -0.35 & -0.58 & -0.50 & -0.41 \\
\hline W Scotian Shelf & 0.55 & 0.63 & -0.79 & -0.20 & -0.15 & -0.21 & 0.19 & 0.33 & 0.65 \\
\hline
\end{tabular}

since 1995, TL $\mathrm{SC}_{.0}$ increased in the South Catalan Sea, Ionian Sea, and Northern Humboldt, all suggesting improvement in the populations of top predators in these ecosystems (as demonstrated by increases in survey and model biomass at TL 4.5 and declines in landings for species at TL 4.5; Fig. 3). These trends appear to correspond to the overall decline in several fishing drivers in the West Coast of Scotland over the full time period, and since the mid- to late-1990s in the other 3 ecosystems (Table 5, 
Fig. 4). However, increases in TLs $>4$ may not correspond to the recovery of previously fished higher TL species, but may instead reflect a shift in the food web whereby other top-level predators are now abundant (e.g. spiny dogfish in the Western Scotian Shelf; Araújo \& Bundy 2012), or the expansion of fisheries to deeper areas. The latter may be the case in the Mediterranean ecosystems (Coll et al. 2014).

In an attempt to classify the 9 ecosystem case studies according to observed trends in TL-based indicators while bearing in mind the exploitation histories (Table 7, Figs. 1-3, Supplement 4), a preliminary conceptual classification emerged:

(1) 'Fishing down' combined with reductions in fishing impacts and landings seems to have occurred in the North Sea (significant declines in $\mathrm{TL}_{\mathrm{L}}, \mathrm{MTI}_{4.0}$, $\mathrm{TL}_{\mathrm{SC}}, \mathrm{TL}_{\mathrm{SC} 3.25}, \mathrm{TL}_{\mathrm{SC} 4.0}$ and Landings ${ }_{3.5 \& 4.5}$ ) and West Coast of Scotland (significant declines in $\mathrm{MTI}_{3.25}$, $\mathrm{MTI}_{4.0}, \mathrm{TL}_{\mathrm{SC}}, \mathrm{TL}_{\mathrm{SC} 3.25}$ and Landings ${ }_{3.5 \& 4.5}$ ), and may also have occurred in the Southern Benguela (significant declines in $\mathrm{TL}_{\mathrm{L}}, \mathrm{TL}_{\mathrm{SC}}$ and $\mathrm{TL}_{\mathrm{MC}}$, non-significant decline in $\mathrm{TL}_{\mathrm{SC} 3.25}$, decreasing trends in Landings $_{3.5 \& 4.5}$ ). However, in the case of the North Sea for example, although high-TL species like tuna and sturgeon have been fished out, there are not clear indications of sequential addition of low-TL species. Guinea has shown some signs of 'fishing down' (significant declines in $\mathrm{MTI}_{4.0}$, and in all 3 model-based $\mathrm{TL}$ indicators, and non-significant declines in the 3 survey-based TL indicators, decline in biomass at TL 3.5 and 4.5 ) but Landings ${ }_{3.5 \& 4.5}$ have increased and there has been an expansion of the fishery in this ecosystem.

(2) 'Fishing up' the food web appears to have occurred in the Northern Humboldt (significant increases in $\mathrm{TL}_{\mathrm{L}}, \mathrm{MTI}_{3.25}, \mathrm{MTI}_{4.0}$, although also in $\mathrm{TL}_{\mathrm{SC} 4.0}$ and $\mathrm{TL}_{\mathrm{MC} 4.0}$, and a significant decline in $\mathrm{TL}_{\mathrm{SC}}$ ).

However, caution should prevail in interpreting situations when fisheries over-exploit low-TL species, or low-TL species collapse due to fishing and detrimental environmental forcing, or a combination thereof. In such cases, TL of the survey and catch may increase despite an underlying collapse of the lower part of the food web. This situation has been recorded for the Northern Benguela (e.g. Cury et al. 2005).

(3) Thus, rather than 'fishing up', 'fisheries expansion' towards 'ecosystem overfishing' may have occurred in the Inner Ionian Sea (significant decline in

Table 7. Expected characteristics associated with trophic level (TL)-based indicators under 3 of the main fishing scenarios considered. ${ }^{*}$ Caution is required when interpreting situations where low-TL species have been overfished or have collapsed due to environmental effects, in which case TL of the survey and catch may increase despite an underlying collapse of the lower part of the food web; this is considered 'ecosystem overfishing' (see 'Results and Discussion: Relating trophic level-based indicators to fishing' for details). See Table 2 for definitions of the TL-based indicators

\begin{tabular}{|c|c|c|c|}
\hline & 'Fishing down' & $\begin{array}{l}\text { 'Fishing through' } \\
\text { (one case of general } \\
\text { expansion) }\end{array}$ & $\begin{array}{l}\text { 'Fishing up' (another } \\
\text { case of general expansion)* }\end{array}$ \\
\hline Summary in words & $\begin{array}{l}\text { Sequential removal of high- } \\
\text { TL fish combined with } \\
\text { sequential addition of low- } \\
\text { TL species in catches } \\
\text { (Pauly et al. 1998) }\end{array}$ & $\begin{array}{l}\text { Sequential addition of low } \\
\text { TLs to catches over time } \\
\text { while maintaining catches } \\
\text { of high-TL species } \\
\text { (Essington et al. 2006) }\end{array}$ & $\begin{array}{l}\text { Addition of new high-TL } \\
\text { species to catches over time } \\
\text { (see Stergiou \& Tsikliras 2011) }\end{array}$ \\
\hline $\begin{array}{l}\text { Expected trend in } \mathrm{TL}_{\mathrm{L}} \\
\text { or } \mathrm{MTI}_{3.25}\end{array}$ & Decline & $\begin{array}{l}\text { Initial decline but then may } \\
\text { level off }\end{array}$ & Increase \\
\hline Expected trend in $\mathrm{MTI}_{4.0}$ & Decline & $\begin{array}{l}\text { Likely to stay same or even } \\
\text { increase as higher TL species } \\
\text { are added }\end{array}$ & Increase or stay same \\
\hline $\begin{array}{l}\text { Expected trend in } \mathrm{TL}_{\mathrm{SC}} \\
\text { or } \mathrm{TL}_{\mathrm{SC} 3.25}\end{array}$ & $\begin{array}{l}\text { Decline but will depend on } \\
\text { what species are surveyed } \\
\text { and extent of surveys }\end{array}$ & $\begin{array}{l}\text { Decline or stay same but } \\
\text { will depend on what species } \\
\text { are surveyed and extent } \\
\text { of surveys }\end{array}$ & $\begin{array}{l}\text { May decline but will depend } \\
\text { on what species are surveyed } \\
\text { and extent of surveys }\end{array}$ \\
\hline Expected trend in $\mathrm{TL}_{\mathrm{SC} 4.0}$ & $\begin{array}{l}\text { Possible decline or stay } \\
\text { same }\end{array}$ & $\begin{array}{l}\text { Possible decline cf. catches, } \\
\text { or stay same }\end{array}$ & $\begin{array}{l}\text { Possible decline, cf. catches, } \\
\text { or stay same }\end{array}$ \\
\hline $\begin{array}{l}\text { Expected trend in catch } \\
\text { of species at TL } 3.5 \text { and } \\
4.5\left(\text { Landings }_{3.5 \& 4.0}\right)\end{array}$ & Decline & Increase or stay same & Increase \\
\hline
\end{tabular}


$\mathrm{MTI}_{3.25}$, significant increases in $\mathrm{TL}_{\mathrm{L}}, \mathrm{MTI}_{4.0}, \mathrm{TL}_{\mathrm{SC}}$ and $\mathrm{TL}_{\mathrm{SC} 4.0}$ and also all 3 model-based TL indicators, increases in Landings 3.5\&4.0 $_{3}$ until the 1990s) and the South Catalan Sea (no significant trends in $\mathrm{TL}_{\mathrm{L}}$ and $\mathrm{TL}_{\mathrm{SC}}$, significant increases in $\mathrm{MTI}_{3.25}, \mathrm{TL}_{\mathrm{SC} 3.25}$ and $\mathrm{TL}_{\mathrm{SC} 4.0}$, significant decline in $\mathrm{TL}_{\mathrm{MC}}$, Landings ${ }_{3.5 \% 4.5}$ declined from the 1990s but are now increasing). This pattern of increases in some TL indicators was not due to an absolute increase of higher TL organisms in the catch, but due to a decline of small pelagic fish species as a result of their depletion (Coll et al. 2008, 2009, 2010a, Piroddi et al. 2010). Recent trends of some TL indicators in the North Central Adriatic and the Southern Benguela may also be early warnings of trajectories towards ecosystem overfishing (Coll et al. 2010b, Shannon et al. 2010) and these systems should be carefully monitored in the future and viewed in the light of what can be deduced also from other ecological indicators.

(4) 'Fishing through' the food web may have occurred in the North Central Adriatic (significant declines in $\mathrm{MTI}_{3.25}, \mathrm{TL}_{\mathrm{SC} 3.25}$ and $\mathrm{TL}_{\mathrm{SC} 4.0}$, no trend in other TLbased indicators, and decline in Landings $3.5 \& 4.5$ until 2000) and possibly also the Western Scotian Shelf ecosystems, although see discussion directly below.

These categories are not mutually exclusive, as illustrated by the results for the Western Scotian Shelf ecosystem (which exhibited significant declines in $\mathrm{TL}_{\mathrm{L}}$ and $\mathrm{MTI}_{3.25}$ and all 3 model-based TL indicators, significant increases in $\mathrm{MTI}_{4.0}$ and $\mathrm{TL}_{\mathrm{SC}}$, decline in Landings $_{3.5 \& 4.0}$ ). Here, these results could be interpreted as 3 of the 4 categories above: 'fishing down', 'fishing through', or 'fisheries expansion' towards 'ecosystem overfishing'. Catches of traditional top predators have decreased, and since then, catches and abundance of dogfish and halibut have increased and there has been some re-direction of effort towards these species, traditional catches have not been maintained, and forage fish (herring) biomass has decreased. There is another alternative, which is that these results may be interpreted as examples of 'balanced harvesting' (Bundy et al. 2005, Garcia et al. 2012, Law et al. 2013), a strategy that balances fishing pressure across trophic levels to maintain trophic structure. There was no trend in $\mathrm{TL}_{\mathrm{SC} 3.25}$ or $\mathrm{TL}_{\mathrm{SC} 4.0}$ in the Western Scotian Shelf (average $\mathrm{TL}_{\mathrm{SC} 3.25}=3.9$, average $\mathrm{TL}_{\mathrm{SC} 4.0}=4.4$ ), suggesting that the trophic structures of the systems are not necessarily changing as a result of fishing in these ecosystems. However, in this case, much of the change is masked by changes in the relative abundance of herring and spiny dogfish, which effectively cancel each other out (see Supplement 1 for further details).
This type of ecosystem classification needs to be fully explored and developed in the near future, for example by means of decision trees, noting that ecosystem type, fishing history and the impact of environmental variability especially at low TLs need to be carefully considered. In summary, information on fishing histories is necessary for interpreting trajectories of TL-based indicators aimed at measuring fishing effects. However, other factors and complexities come in to play as well. We may expect lags in detection of ecosystem response to fishing pressure or fishing strategy (e.g. Fung et al. 2013), confounded by the influence of environmental drivers, which are dealt with in the following section.

\section{TL-based indicators in the context of environmental variability}

Trends in chl a over time varied across ecosystems and no clear pattern emerged between chl $a$ and TL-based indicators (Table 8a). Chl a patterns were only significantly correlated with TL-based indicators in $16 \%$ of the cases; in $62 \%$ of the cases this interaction was negative and significant, while $38 \%$ of the significant cases were positive. However, Guinea was an exception: chl a correlated significantly with all catch-based and survey-based TL indicators, suggesting that in this ecosystem alone, productivity could have been a strong explanatory factor in TL trends observed in landings and survey data. A notable increase in chl a was observed only in the North Central Adriatic Sea (Table 8a). On the West Coast of Scotland, chl $a$ and $\mathrm{TL}_{\mathrm{SC} 3.25}$ were positively related, whereas when non-surveyed species and all TLs were also taken into account (by $\mathrm{TL}_{\mathrm{MC}}$ ), a negative relationship was found with chl $a$, possibly highlighting food web effects such as bottom-up forcing of lower TL groups such as Nephrops norvegicus. This illustrates the problem with using survey communities only, as the pelagic food web and invertebrates of the West Coast of Scotland were under-surveyed. These communities were to some extent included in the $\mathrm{TL}_{\mathrm{MC}}$, which was significantly correlated with $\mathrm{chl} a$. In the North Central Adriatic and Ionian seas, a strong and negative relationship emerged between chl a and $\mathrm{TL}_{\mathrm{L}}$, which may indicate processes of higher recruitment and an increase of juveniles in the catch due to the low selectivity of main commercial fleets, such as bottom trawling in the Mediterranean Sea (and in general in European seas) (Colloca et al. 2013, Sarda et al. 2013). 
Table 8. Correlation coefficients for (a) chl $a$ and (b) sea surface temperature (SST) against year and trophic level (TL)-based indicators. Bold values in shaded cells indicate significant $(\mathrm{p}<0.05)$ correlations: dark grey = positive, light grey = negative. See Table 2 for definitions of the TL-based indicators

\begin{tabular}{|c|c|c|c|c|c|c|c|c|c|c|c|c|}
\hline (a) $\mathrm{Chl} \mathrm{a}$ & SST & Year & Landings & $\mathrm{TL}_{\mathrm{L}}$ & $\mathrm{MTI}_{3.25}$ & $\mathrm{MTI}_{4.0}$ & $\mathrm{TL}_{\mathrm{SC}}$ & $\mathrm{TL}_{\mathrm{SC} 3.25}$ & $\mathrm{TL}_{\mathrm{SC} 4.0}$ & $\mathrm{TL}_{\mathrm{MC}}$ & $\mathrm{TL}_{\mathrm{MC} 3.25}$ & $\mathrm{TL}_{\mathrm{MC} 4.0}$ \\
\hline NC Adriatic Sea & -0.07 & 0.74 & -0.40 & -1.00 & NA & 0.40 & 0.50 & 0.50 & 0.50 & NA & NA & NA \\
\hline S Benguela & 0.43 & 0.05 & -0.07 & -0.24 & 0.24 & & 0.00 & -0.55 & 0.26 & NA & NA & NA \\
\hline S Catalan Sea & -0.05 & -0.69 & -0.21 & -0.02 & -0.19 & 0.10 & 0.17 & 0.17 & -0.26 & 0.40 & -0.40 & 0.29 \\
\hline Guinean EEZ & 0.24 & 0.29 & & -1.00 & 1.00 & 1.00 & -1.00 & -1.00 & -1.00 & -0.29 & -0.29 & 0.29 \\
\hline Inner Ionian Sea & -0.45 & 0.40 & 0.09 & -1.00 & 0.80 & 0.30 & 0.70 & -0.70 & 0.30 & 0.30 & 0.50 & 0.90 \\
\hline Northern Humboldt & -0.33 & 44 & & 0.33 & & & -0.16 & & 0.47 & -0.75 & 0.14 & 0.67 \\
\hline N Sea & 0.14 & 0.48 & -0.69 & -0.55 & -0.43 & 0.60 & 0.10 & 0.10 & -0.19 & 0.60 & -0.60 & 0.90 \\
\hline W Coast Scotland & 0.69 & -0.19 & & -0.54 & -0.09 & -0.83 & -0.10 & 0.90 & -0.60 & -0.94 & 0.20 & 0.03 \\
\hline W Scotian Shelf & 0.50 & 0.67 & -0.64 & 0.60 & -0.45 & -0.12 & -0.52 & -0.52 & -0.62 & 0.09 & -0.43 & -0.20 \\
\hline (b) SST & $\operatorname{chl} a$ & Year & Landings & $\mathrm{TL}_{\mathrm{L}}$ & $\mathrm{MTI}_{3.25}$ & $\mathrm{MTI}_{4.0}$ & $\mathrm{TL}_{\mathrm{SC}}$ & $\mathrm{TL}_{\mathrm{SC} 3.25}$ & $\mathrm{TL}_{\mathrm{SC} 4.0}$ & $\mathrm{TL}_{\mathrm{MC}}$ & $\mathrm{TL}_{\mathrm{MC} 3.25}$ & $\mathrm{TL}_{\mathrm{MC} 4.0}$ \\
\hline NC Adriatic Sea & -0.07 & 0.67 & -0.53 & -0.07 & -0.04 & 0.10 & -0.29 & -0.40 & -0.14 & -0.17 & 0.03 & -0.05 \\
\hline S Beng & -0.43 & & & -0.57 & & & -0.55 & -0.32 & 0.15 & & -0.32 & -0.37 \\
\hline S Catalan Sea & -0.05 & 0.67 & -0.48 & -0.27 & 0.34 & -0.03 & -0.39 & 0.31 & 0.35 & -0.75 & 0.35 & -0.20 \\
\hline Guinean EEZ & 0.24 & & & -0.02 & & -0.52 & -0.50 & -0.22 & -0.54 & -0.72 & -0.72 & -0.41 \\
\hline Inner Ionian Sea & -0.45 & 0.65 & -0.25 & 0.53 & -0.44 & 0.26 & 0.41 & -0.04 & 0.70 & 0.35 & 0.53 & 0.25 \\
\hline Northern Humboldt & -0.33 & -0.08 & -0.14 & -0.01 & & -0.09 & 0.32 & 0.22 & -0.15 & 0.28 & 0.27 & -0.17 \\
\hline N Sea & 0.14 & 0.75 & -0.53 & -0.20 & -0.15 & -0.64 & -0.49 & -0.48 & -0.37 & -0.60 & -0.12 & -0.61 \\
\hline W Coast Scotland & 0.69 & 0.85 & -0.63 & -0.30 & -0.70 & -0.41 & -0.57 & -0.56 & 0.65 & 0.81 & 0.76 & 0.82 \\
\hline W Scotian Shelf & 0.50 & 0.33 & -0.38 & -0.40 & -0.23 & 0.39 & -0.03 & -0.04 & 0.11 & 0.01 & -0.20 & -0.24 \\
\hline
\end{tabular}

Significant correlations of SST and TL-based indicators were more numerous $(36 \%$ of total pairs correlated) than in the case of chl a patterns (Table 8b). In 7 of the 9 case studies, SST increased significantly with time, and this had a general negative impact on $69 \%$ of the TL-based indicators that were significantly correlated with SST (Table 8b), suggesting an overall negative impact of sea surface warming on landings and the trophic level of marine communities. However, $31 \%$ of the significant correlations between SST and TL-based indicators were positive. Interestingly, in 5 ecosystems, SST and landings were negatively and significantly correlated (Table 8b). However, a significant positive correlation was found between SST and landings in Guinea, where SST increased over the studied period. At the same time, the biomass of high-TL species off Guinea decreased (Fig. 3), although this is likely a result of the strong increase in fishing effort rather than from any environmental effect. Even if a shift to lower TL species might be reinforced by an increase in SST, this correlation mainly appeared as an artefact.

Survey- and model-based TL indicators showed a greater number of significant correlations with SST than catch-based TL indicators (Table 8b), which would be expected given that the surveyed community is likely to better capture effects of both fishing and environmental variability. SST was significantly correlated with $\mathrm{TL}_{\mathrm{SC}}$ and $\mathrm{TL}_{\mathrm{MC}}$ in 5 of the 9 ecosys- tems examined in each case, suggesting that relationships of TL-based indicators to SST may be better captured by looking at the full community (excluding plankton) that includes non-surveyed groups, which are often located at either low or high TLs. Nevertheless, in the case of model-based TL indicators, correlations with SST may also reflect the fact that most of these models are either forced by, or fit to, some form of environmental data series (e.g. Mackinson et al. 2009), although not necessarily the temperature series used here.

\section{Further insights from trophic spectra}

Analysing indicators derived from size spectra may help interpretation of TL indicator trajectories. For instance, the North Sea and West Coast of Scotland seem to have experienced a 'fishing down' the food web history. However, looking more precisely at particular trophic levels (Fig. 3), it appears that landings of all TLs have declined in the former ecosystem, whereas in the latter, TL 4.5 has decreased when TL 3.5 remains stable and landings of TL 2.5 has increased-illustrating a shift from landing species with high TLs towards targeting species with low TLs. In the North Sea, landings of low, intermediate and high TLs showed similar trajectories. Similarly, there was agreement amongst TL 2.5, 3.5 and 4.5 tra- 
jectories in the North Central Adriatic, Guinea and Inner Ionian Sea, reflecting homogeneous changes across the trophic spectrum in those ecosystems.

Comparing patterns of TL95th and patterns of the width of the trophic spectrum (Fig. S4 in Supplement 5 at www.int-res.com/articles/suppl/m512p115_ supp.pdf) allows us to determine the causes of variations: if both patterns are similar, variations of the width are only due to variation of TL95th, and patterns are due to changes at the upper end of the trophic spectrum; conversely, if patterns are different, variations of the width of the trophic spectrum involve variations at the base of the food web. Results showed high similarity between the trajectories of both $\mathrm{TL}_{95 \text { th }}$ and trophic spectrum width, which indicated that patterns of these indicators were generally due to changes in the upper part of the trophic spectrum and not at the base. This was coherent with the previous results of poor correlations between environment and TL indicators, as it is likely that the environment would have impacted the base of the trophic spectrum.

\section{CONCLUDING REMARKS}

Are TL-based indicators useful? Branch et al. (2010) concluded that catch-based TL indicators are not useful indicators of fishing impacts and changes in marine biodiversity since they do not reliably predict changes in marine ecosystems. However, for some ecosystems in that study, the area from which catch data were readily available did not match the delineated ecosystems under investigation. Correcting for this through access to local data, and using more extensive survey-based indicators (Shin et al. 2010, 2012) improves on those results presented for some ecosystems. There are many potential explanations for the apparent discrepancies in results obtained by Branch et al. (2010) compared to those from Pauly et al. (1998) and to regional case studies (see www.fishingdown.org), including misreporting of, and/or biases in catch statistics, mismatch of catch and survey areas, and that surveys in many of the ecosystems examined do not measure abundance of low-TL species that are often caught in large quantities (but discarded), and which are subject to fluctuations of large amplitudes. The expansion in fishing area over time (Swartz et al. 2010) is another possible explanation for the increase in $\mathrm{MTI}_{3.25}$ observed in many areas from the 1980s which should be accounted for (Kleisner et al. 2014, this Theme Section). An increase in $\mathrm{MTI}_{3.25}$ may mask the fact that near-shore fisheries have been fished down, with fisheries consequently moving further offshore. Moreover, surveys in different ecosystems capture different species of benthic, demersal and pelagic components in different ways and to different extents. Thus, comparisons across ecosystems, large marine ecosystems or regions must be carefully drawn when different datasets are combined.

In this study, we have explored the use of different data sources to calculate TL-based indicators with 3 cut-off points, and contrary to Branch et al. (2010), we conclude that TL-based indicators are useful - especially when all 3 data sources and cut-off points are used, which together can shape a more complete understanding of the effects of fishing on the trophic structure of ecosystems. However, TL-based indicators, as with any indicator, need to be interpreted within regional or local information. This study has provided new information about the utility of TLbased indicators, and specifically recommends that TL-based indicators should not be used without contextual information about the history of exploitation in the fishery and fundamental knowledge of ecological changes and environmental drivers. Stergiou \& Tsikliras (2011) suggest that TL-based indicators may be helpful as a means of assessing changes in species at higher TLs only, although the authors cautioned that such indicators must be interpreted with care as confounding effects need disentangling. Our results confirm this caution, but augment it with the recommendation that all types of TL-based indicators should be used. The difference between TL-based indicator values and trends is dependent on the data source and cut-off point, not to an intrinsic problem with TL-based indicators. Here, we have shown that survey-based data augmented by trophic model data was illuminating in terms of improving our understanding of observed changes in fished ecosystems.

Technicalities related to fishing behaviour often underlie trends in TL-based indicators of landed catch, leading Stergiou \& Tsikliras (2011) to push for inclusion of ecosystem experts in interpretation of such indicators. Based on fishing history, knowledge about the environmental drivers, ecology of the systems and the information from the 9 TL-based indicators, we used a conceptual typology to classify the 9 ecosystems into 4 types: 'fishing down', 'fishing through', 'fishing up', and general expansion of fisheries leading to 'ecosystem overfishing'. TL-based indicators may respond differently under these typologies, which can be sequenced in time. Importantly, our study indicates that the inclusion of ecosystem experts is essential. Without this knowledge, this type of comparative classification would not be pos- 
sible. The current study relied on local expertise, local survey and catch data (a strength of the IndiSeas project, www.indiseas.org; Shin \& Shannon 2010, Shin et al. 2012), as opposed to the more easily accessible yet aggregated data used in global meta-analyses. The latter may result in individual differences being masked as a result of the aggregation of data from different ecosystems which may exhibit different dynamics.

Comparing TL-based indicators across the 9 case studies using catch, survey and model data, the following general statements can be made:

(1) Catch-based TL indicators do not necessarily reflect what is happening at the community and ecosystem level since non-targeted and discarded or unreported species may not be considered;

(2) Catch-based indicators are indicators of pressure and respond sensitively to management action but are not specific indicators of change in state. Importantly, they often cover a longer period of time and provide a measure of the spread of pressure across TLs;

(3) Survey-based TL indicators may be more encompassing than catch-based TL indicators, but survey-based are nonetheless also a limited information source given that they are based on a subset of those species present, especially where only part of the ecosystem is surveyed. Where possible, combining data from different surveys (e.g. pelagic and demersal surveys) in the same ecosystem should be explored;

(4) Model-based TL indicators may facilitate the inclusion of non-sampled or poorly sampled species in ecosystem assessments (although there is uncertainty in parameterization of models depending on data availability and quality, similar to data issues in catch and surveys);

(5) The exploitation history (in time and space) and the implementation of fisheries management measures in an ecosystem can influence what we can readily deduce from TL-based indicators, and should be taken into account when interpreting these indicators;

(6) Expert knowledge of an ecosystem, including environmental and fishing drivers (and including implementation of management measures) operating in the system, are essential in global comparisons of fishing effects in marine ecosystems;

(7) In global comparisons, in order to accommodate ecosystems in which low-TL species dominate catches or catch variability (e.g. upwelling systems), comparing trends in $\mathrm{TL}_{\mathrm{L}}$ is recommended in addition to $\mathrm{MTI}_{3.25}$. Further, $\mathrm{TL}_{\mathrm{SC}}$ provides a fuller picture of what is happening at the community level and may capture combined effects of fishing and the environment more clearly (and possibly with less of a time lag) than $\mathrm{TL}_{\mathrm{L}}$ or $\mathrm{MTI}_{3.25}$. In addition and when available, $\mathrm{TL}_{\mathrm{MC}}$ indicators should be included in the analysis to verify the inclusion of essential ecosystem processes in $\mathrm{TL}_{\mathrm{L}}$ and $\mathrm{TL}_{\mathrm{SC}}$ indicators;

(8) All 3 types of TL indicators (catch-, survey- and model-based) provide information that is useful for ecosystem-based fisheries management.

Acknowledgements. We are extremely grateful to Hervé Demarcq (IRD, France) for making available to us the chlorophyll and sea surface temperature data he extracted and worked up for the 9 ecosystems examined in our study. Advice from Steve Mackinson (CEFAS, UK) regarding the North Sea model was greatly appreciated. L.J.S. was supported through the South African Research Chair Initiative, funded through the South African Department of Science and Technology (DST) and administered by the South African National Research Foundation (NRF). M.C. was supported by the European Commission through the Marie Curie CIG grant to BIOWEB and the Spanish Research Program Ramon y Cajal. Y.J.S. and M.T. were supported by the French project EMIBIOS (FRB, contract no. APP-SCEN2010-II). L.J.S. and Y.S. were also funded by the European collaborative project MEECE - Marine Ecosystem Evolution in a Changing Environment - (FP7, contract $\left.n^{\circ} 212085\right)$. A.B. was supported by Fisheries and Oceans Canada SPERA project 'Ecosystem indicators for ecosystem monitoring at different scales' (www.dfo-mpo.gc.ca/science/ecosystem/ projects/detail-eng.asp?pid=21). K.K. was supported by Conservation International and the 'Sea Around Us' project, a collaboration between The University of British Columbia and The Pew Charitable Trusts. C.P.L. and C.P. were supported by the EU FP7 project DEVOTES (grant agreement no. 308392), www.devotes-project.eu. C.P.L. was also supported by Defra M1228. This is a contribution to the IndiSeas Working Group, endorsed by IOC-UNESCO (www.iocunesco.org) and the European Network of Excellence Euroceans (www.eur-oceans.eu).

\section{LITERATURE CITED}

Alexander KA (2012) Offshore power production and marine stakeholders: from understanding conflict to impact mitigation. $\mathrm{PhD}$ thesis, University of Aberdeen

Anderson SC, Flemming JM, Watson R, Lotze HK (2011a) Rapid global expansion of invertebrate fisheries: trends, drivers, and ecosystem effects. PLoS ONE 6:e14735

Anderson SC, Flemming JM, Watson R, Lotze HK (2011b) Serial exploitation of global sea cucumber fisheries. Fish Fish 12:317-339

Arancibia H, Neira S (2005) Long-term changes in the mean trophic level of Central Chile fishery landings. Sci Mar 69:295-300

Araújo JN, Bundy A (2012) Effects of environmental change, fisheries and trophodynamics on the ecosystem of the western Scotian Shelf, Canada. Mar Ecol Prog Ser 464: 51-67

Baum JK, Worm B (2009) Cascading top-down effects of 
changing oceanic predator abundances. J Anim Ecol 78: 699-714

Bhathal B, Pauly D (2008) 'Fishing down marine food webs' and spatial expansion of coastal fisheries in India, 1950-2000. Fish Res 91:26-34

Bianchi G, Gislason H, Graham K, Hill L and others (2000) Impact of fishing on size composition and diversity of demersal fish communities. ICES J Mar Sci 57:558-571

Blanchard JL, Coll M, Trenkel VM, Vergnon R and others (2010) Trend analysis of indicators: a comparison of recent changes in the status of marine ecosystems around the world. ICES J Mar Sci 67:732-744

> Branch TA, Watson R, Fulton EA, Jennings S and others (2010) The trophic fingerprint of marine fisheries. Nature 468:431-435

Bundy A, Fanning LP (2005) Can Atlantic cod (Gadus morhua) recover? Exploring trophic explanations for the non-recovery of the cod stock on the eastern Scotian Shelf, Canada. Can J Fish Aquat Sci 62:1474-1489

> Bundy A, Fanning P, Zwanenburg KTC (2005) Balancing exploitation and conservation of the eastern Scotian Shelf ecosystem: application of a 4D ecosystem exploitation index. ICES J Mar Sci 62:503-510

Butchart SH, Walpole M, Collen B, van Strien A and others (2010) Global biodiversity: indicators of recent declines. Science 328:1164-1168

> Caddy J, Csirke J, Garcia S, Grainger R (1998) How pervasive is 'fishing down marine food webs'? Science 282: 1383

CBD (2004) Decisions adopted by the conference of the parties to the convention on biological diversity at its sixth meeting. Report on the Sixth Meeting of the Conference of the Parties to the Convention on Biological Diversity (UNEP/CBD/COP/6/20/Part 2), Strategic Plan Decision VI/26, The Hague, 7-19 April 2002

- Christensen V (1998) Fishery-induced changes in a marine ecosystem: insight from models of the Gulf of Thailand. J Fish Biol 53:128-142

> Christensen V, Walters CJ (2004) Ecopath with Ecosim: methods, capabilities and limitations. Ecol Modell 172: 109-139

Coll M, Palomera I, Tudela S, Dowd M (2008) Food-web dynamics in the South Catalan Sea ecosystem (NW Mediterranean) for 1978-2003. Ecol Modell 217:95-116

- Coll M, Santojanni A, Palomera I, Arneri E (2009) Food-web changes in the Adriatic Sea over the last three decades. Mar Ecol Prog Ser 381:17-37

> Coll M, Santojanni A, Palomera I, Arneri E (2010a) Ecosystem assessment of the North-Central Adriatic Sea: towards a multivariate reference framework. Mar Ecol Prog Ser 417:193-210

Coll M, Shannon LJ, Yemane D, Link JS and others (2010b) Ranking the ecological relative status of exploited marine ecosystems. ICES J Mar Sci 67:769-786

Coll M, Carreras M, Ciércoles C, Cornax M, Morote E, Saez $\mathrm{R}$ (2014) Assessing fishing and marine biodiversity changes using fishers' perceptions: the Spanish Mediterranean and Gulf of Cadiz case study. PLoS ONE 9: e85670

> Colléter M, Gascuel D, Ecoutin JM, Tito de Morais L (2012) Modelling trophic flows in ecosystems to assess the efficiency of marine protected area (MPA), a case study on the coast of Sénégal. Ecol Modell 232:1-13

Colloca F, Cardinale M, Maynou F, Giannoulaki M and others (2013) Rebuilding Mediterranean fisheries: a new paradigm for ecological sustainability. Fish Fish 14: 89-109

Cury P, Shannon L, Roux J, Daskalov G, Jarre A, Moloney C, Pauly D (2005) Trophodynamic indicators for an ecosystem approach to fisheries. ICES J Mar Sci 62:430-442

Degnbol P, Jarre A (2004) Review of indicators in fisheries management - a development perspective. Afr J Mar Sci 26:303-326

DFO (2007) Assessment of spiny dogfish in Atlantic Canada. Department of Fisheries and Oceans Canada, Science Advisory Report No. 2007/046

- Essington TE, Beaudreau AH, Wiedenmann J (2006) Fishing through marine food webs. Proc Natl Acad Sci USA 103: 3171-3175

FAO-GFCM (2013) Report of the fifteenth session of the Scientific Advisory Committee. FAO Fish Aquac Rep No. 1042, Rome

Frank KT, Petrie B, Choi JS, Leggett WC (2005) Trophic cascades in a formerly cod-dominated ecosystem. Science 308:1621-1623

Fung T, Farnsworth KD, Shephard S, Reid DG, Rossberg AG (2013) Why the size structure of marine communities can require decades to recover from fishing. Mar Ecol Prog Ser 484:155-171

Garcia SM, Kolding J, Rice J, Rochet MJ and others (2012) Reconsidering the consequences of selective fisheries. Science 335:1045-1047

> Garibaldi L (2012) The FAO global capture production database: a six-decade effort to catch the trend. Mar Policy 36:760-768

Gasche L, Gascuel D, Shannon L, Shin YJ (2012) Global assessment of the fishing impacts on the Southern Benguela ecosystem using an EcoTroph modelling approach. J Mar Syst 90:1-12

> Gascuel D, Pauly D (2009) EcoTroph: modelling marine ecosystem functioning and impact of fishing. Ecol Modell 220:2885-2898

> Gascuel D, Bozec YM, Chassot E, Colomb A, Laurans M (2005) The trophic spectrum: theory and application as an ecosystem indicator. ICES J Mar Sci 62:443-452

> Gascuel D, Labrosse P, Meissa B, Taleb Sidi MO, Guénette S (2007) Decline of demersal resources in North-West Africa: an analysis of Mauritanian trawl survey data over the last 25 years. Afr J Mar Sci 29:331-345

> Gascuel D, Morissette L, Palomares D, Christensen V (2008) Trophic flow kinetics in marine ecosystems: toward a theoretical approach to ecosystem functioning. Ecol Modell 217:33-47

Gascuel D, Tremblay-Boyer L, Pauly D (2009a) EcoTroph (ET): a trophic level based software for assessing the impacts of fishing on aquatic ecosystems. Fisheries Centre Research Reports, 17(1), University of British Columbia, Vancouver

Gascuel D, Guénette S, Diallo I, Sidibé A (2009b) Impact de la pêche sur l'écosystème marin de Guinée - modélisation EwE 1985/2005. Fisheries Centre Research Reports, 17(4), University of British Columbia, Vancouver (in French with English Abstract)

Gascuel D, Guénette S, Pauly D (2011) The trophic-levelbased ecosystem modelling approach: theoretical overview and practical uses. ICES J Mar Sci 68:1403-1416

Harley SJ, Myers RA (2001) Hierarchical Bayesian models of length-specific catchability of research trawl surveys. Can J Fish Aquat Sci 58:1569-1584

Heath MR (2005) Regional variability in the trophic require- 
ments of shelf sea fisheries in the Northeast Atlantic, 1973-2000. ICES J Mar Sci 62:1233-1244

- Heath MR, Speirs DC (2012) Changes in species diversity and size composition in the Firth of Clyde demersal fish community (1927-2009). Proc Biol Sci 279:543-552

Hilborn R, Walters CJ (1992) Quantitative fisheries stock assessment: choice, dynamics and uncertainty. Chapman \& Hall, New York, NY

Howarth LM, Roberts CM, Thurstan RH, Stewart BD (2013) The unintended consequences of simplifying the sea: making the case for complexity. Fish Fish, doi:10.1111/ faf.12041

> Hückstädt LA, Rojas C, Antezana T (2007) Stable isotope analysis reveals pelagic foraging by the southern sea lion in central Chile. J Exp Mar Biol Ecol 347:123-133

> Jennings S, Greenstreet S, Reynolds J (1999) Structural change in an exploited fish community: a consequence of differential fishing effects on species with contrasting life histories. J Anim Ecol 68:617-627

> Jennings S, Greenstreet S, Hill L, Piet G, Pinnegar J, Warr KJ (2002) Long-term trends in the trophic structure of the North Sea fish community: evidence from stable-isotope analysis, size-spectra and community metrics. Mar Biol 141:1085-1097

Jouffre D, de Fatima Borges M, Bundy A, Coll M and others (2010) Estimating EAF indicators from scientific trawl surveys: theoretical and practical concerns. ICES J Mar Sci 67:796-806

Kleisner K, Mansour H, Pauly D (2014) Region-based MTI: resolving geographic expansion in the Marine Trophic Index. Mar Ecol Prog Ser 512:185-199

> Lassalle G, Gascuel D, Le Loc'h F, Lobry J and others (2012) An ecosystem approach for the assessment of fisheries impacts on marine top predators: the Bay of Biscay case study. ICES J Mar Sci 69:925-938

> Laurans M, Gascuel D, Chassot E, Thiam D (2004) Changes in the trophic structure of fish demersal communities in West Africa in the three last decades. Aquat Living Resour 17:163-174

> Law R, Kolding J, Plank MJ (2013) Squaring the circle: reconciling fishing and conservation of aquatic ecosystems. Fish Fish, doi:10.1111/faf.12056

Lindeman RL (1942) The trophic-dynamic aspect of ecology. Ecology 23:399-417

Lotze HK, Coll M, Magera AM, Ward-Paige C, Airoldi L (2011) Recovery of marine animal populations and ecosystems. Trends Ecol Evol 26:595-605

Mackinson S, Daskalov G, Heymans JJ, Neira S and others (2009) Which forcing factors fit? Using ecosystem models to investigate the relative influence of fishing and changes in primary productivity on the dynamics of marine ecosystems. Ecol Modell 220:2972-2987

> Marzloff M, Shin YJ, Tam J, Travers M, Bertrand A (2009) Trophic structure of the Peruvian marine ecosystem in 2000-2006: insights on the effects of management scenarios for the hake fishery using the IBM trophic model Osmose. J Mar Syst 75:290-304

> Morato T, Watson R, Pitcher TJ, Pauly D (2006) Fishing down the deep. Fish Fish 7:24-34

Odum WE, Heald EJ (1975) The detritus-based food web for an estuarine mangrove community. In: Cronin LE (ed) Estuarine research, Vol 1. Academic Press, New York, NY, p 265-286

Osman W (2010) Trophic model-generated indicators of the southern Benguela ecosystem for communicating with fisheries managers. MSc thesis, University of Cape Town > Palomera I, Olivar MP, Salat J, Sabatés A, Coll M, García A, Morales-Nin B (2007) Small pelagic fish in the NW Mediterranean Sea: an ecological review. Prog Oceanogr 74: 377-396

Pang L, Pauly D (2001) Chinese marine capture fisheries from 1950 to the late 1990s: the hopes, the plans and the data. In: Watson R, Pang L, Pauly D (eds) The marine fisheries of China: development and reported catches. Fisheries Centre Research Report, 9(2). University of British Columbia, Vancouver, p 1-27

Pauly D, Palomares ML (2000) Approaches for dealing with three sources of bias when studying the fishing down marine food web phenomenon. In Durand F (ed) Fishing down the Mediterranean food webs? CIESM Workshop Series No. 12, CIESM, Kerkyra, p 61-66

Pauly D, Palomares ML (2005) Fishing down marine food web: it is far more pervasive than we thought. Bull Mar Sci 76:197-212

Pauly D, Watson R (2005) Background and interpretation of the 'Marine Trophic Index' as a measure of biodiversity. Philos Trans R Soc Lond B Biol Sci 360:415-423

> Pauly D, Christensen V, Dalsgaard J, Froese R, Torres F (1998) Fishing down marine food webs. Science 279:860-863

Pauly D, Christensen V, Froese R, Palomares M (2000) Fishing down aquatic food webs. Am Sci 88:46-51

> Pauly D, Palomares ML, Froese R, Sa-a P, Vakily M, Preikshot D, Wallace S (2001) Fishing down Canadian aquatic food webs. Can J Fish Aquat Sci 58:51-62

Pikitch E, Boersma P, Boyd I, Conover D and others (2012) Little fish, big impact: managing a crucial link in ocean food webs. Lenfest Ocean Program, Washington, DC

> Piroddi C, Giovanni B, Villy C (2010) Effects of local fisheries and ocean productivity on the northeastern Ionian Sea ecosystem. Ecol Modell 221:1526-1544

Ramsvatn S (2013) Investigating coastal ecosystem structure and dynamics using Ecopath mass-balance modelling and stable isotope data. PhD thesis, University of Tromsø

Rochet MJ, Trenkel VM (2003) Which community indicators can measure the impact of fishing? A review and proposals. Can J Fish Aquat Sci 60:86-99

> Sarda F, Coll M, Heymans JJ, Stergiou KI (2013) Overlooked impacts and challenges of the new European discard ban. Fish Fish, doi:10.1111/faf.12060

Scheffer M, Carpenter S, de Young B (2005) Cascading effects of overfishing marine systems. Trends Ecol Evol 20:579-581

Shannon LJ, Moloney CL, Jarre A, Field JG (2003) Trophic flows in the southern Benguela during the 1980s and 1990s. J Mar Syst 39:83-116

> Shannon L, Christensen V, Walters C (2004) Modelling stock dynamics in the southern Benguela ecosystem for the period 1978-2002. Afr J Mar Sci 26:179-196

Shannon L, Neira S, Taylor M (2008) Comparing internal and external drivers in the southern Benguela and the southern and northern Humboldt upwelling ecosystems. Afr J Mar Sci 30:63-84

Shannon LJ, Coll M, Neira S (2009) Exploring the dynamics of ecological indicators using food web models fitted to time series of abundance and catch data. Ecol Indic 9: 1078-1095

Shannon LJ, Coll M, Yemane D, Jouffre D and others (2010) Comparing data-based indicators across upwelling and comparable systems for communicating ecosystem states and trends. ICES J Mar Sci 67:807-832 
Shin YJ, Shannon LJ (2010) Using indicators for evaluating, comparing, and communicating the ecological status of exploited marine ecosystems. 1. The IndiSeas project. ICES J Mar Sci 67:686-691

Shin YJ, Rochet MJ, Jennings S, Field JG, Gislason H (2005) Using size-based indicators to evaluate the ecosystem effects of fishing. ICES J Mar Sci 62:384-396

Shin YJ, Shannon LJ, Bundy A, Coll M and others (2010) Using indicators for evaluating, comparing, and communicating the ecological status of exploited marine ecosystems. 2. Setting the scene. ICES J Mar Sci 67:692-716

Shin YJ, Bundy A, Shannon LJ, Blanchard JL and others (2012) Global in scope and regionally rich: an IndiSeas workshop helps shape the future of marine ecosystem indicators. Rev Fish Biol Fish 22:835-845

Spearman C (1904) The proof and measurement of association between two things. Am J Psychol 15:72-101

STECF (Scientific, Technical and Economic Committee for Fisheries) (2013) 2012 Assessment of Mediterranean Sea stocks part II (STECF 13-05). Publications Office of the European Union, Luxembourg

Steneck RS, Vavrinec J, Leland AV (2004) Accelerating trophic-level dysfunction in kelp forest ecosystems of the western North Atlantic. Ecosystems 7:323-332

Stergiou KI (2005) Fisheries impact on trophic levels: longterm trends in Hellenic waters. In: Papathanassiou E, Zenetosa A (eds) State of the Hellenic marine environment. Hellenic Centre for Marine Research, Institute of Oceanography, Athens, p 326-329

Stergiou K, Christensen V (2011) Fishing down food webs. Ecosystem approaches to fisheries: a global perspective. Cambridge University Press, p 72-88

Stergiou KI, Tsikliras AC (2011) Fishing down, fishing through and fishing up: fundamental process versus technical details. Mar Ecol Prog Ser 441:295-301

Swartz W, Sala E, Tracey S, Watson R, Pauly D (2010) The spatial expansion and ecological footprint of fisheries (1950 to present). PLoS ONE 5:e15143

Thorson JT, Clarke ME, Stewart IJ, Punt AE, Sainte-Marie B (2013) The implications of spatially varying catchability on bottom trawl surveys of fish abundance: a proposed solution involving underwater vehicles. Can J Fish Aquat Sci 70:294-306

Thurstan RH, Roberts CM (2010) Ecological meltdown in the Firth of Clyde, Scotland: two centuries of change in a coastal marine ecosystem. PLoS ONE 5:e11767

Travers-Trolet M, Shin YJ, Field JG (2014) An end-to-end coupled model ROMS- $\mathrm{N}_{2} \mathrm{P}_{2} \mathrm{Z}_{2} \mathrm{D}_{2}$-OSMOSE of the southern Benguela food web: parameterization, calibration and pattern-oriented validation. Afr J Mar Sci, doi: 10.2989/1814232X.2014.883326

Valls A, Gascuel D, Guénette S, Francour P (2012) Modeling trophic interactions to assess the effects of a marine protected area: case study in the NW Mediterranean Sea. Mar Ecol Prog Ser 456:201-214

Van der Lingen CD, Miller TW (2011) Trophic dynamics of pelagic nekton in the southern Benguela Current Ecosystem: calibrating trophic models with stable isotope analysis. In: Omori K, Guo X, Yoshie N, Fujii N, Handoh IC, Isobe A, Tanabe $\mathrm{S}$ (eds) Interdisciplinary studies on environmental chemistry, Vol 5: marine environmental modeling \& analysis. Terrapub, Tokyo, p 85-94

- Vinagre C, Salgado J, Mendonça V, Cabral H, Costa M (2012) Isotopes reveal fluctuation in trophic levels of estuarine organisms, in space and time. J Sea Res 72: 49-54

Ward P, Myers RA (2005) Shifts in open-ocean fish communities coinciding with the commencement of commercial fishing. Ecology 86:835-847

Watermeyer K, Shannon L, Griffiths C (2008) Changes in the trophic structure of the southern Benguela before and after the onset of industrial fishing. Afr J Mar Sci 30: 351-382

- Watson RA, Cheung WW, Anticamara JA, Sumaila RU, Zeller D, Pauly D (2013) Global marine yield halved as fishing intensity redoubles. Fish Fish 14:493-503

Wing S, Wing E (2001) Prehistoric fisheries in the Caribbean. Coral Reefs 20:1-8

Zeller D, Pauly D (2007) Reconstruction of marine fisheries catches for key countries and regions (1950-2005). Fisheries Centre Research Reports, 15(2). University of British Columbia, Vancouver

Proofs received from author(s): July 23, 2014 